\title{
Genomic data mining of the marine actinobacteria Streptomyces sp. H-KF8 unveils insights into multi-stress related genes and metabolic pathways involved in antimicrobial synthesis
}

\author{
Agustina Undabarrena $^{1}$, Juan A Ugalde ${ }^{2,3}$, Michael Seeger ${ }^{4}$, Beatriz Cámara ${ }^{\text {Corresp. } 1}$ \\ 1 Departmento de Química y Centro de Biotecnología, Universidad Técnica Federico Santa María, Valparaiso, Chile \\ 2 Centro de Genética y Genómica, Facultad de Medicina Clinica Alemana, Universidad del Desarrollo, Santiago, Chile \\ 3 Programa de Genómica Microbiana, Facultad de Medicina Clinica Alemana, Universidad del Desarrollo, Santiago, Chile \\ 4 Departmento de Química \& Centro de Biotecnología, Universidad Técnica Federico Santa María, Valparaiso, Chile \\ Corresponding Author: Beatriz Cámara \\ Email address: beatriz.camara@usm.cl
}

Streptomyces sp. H-KF8 is an actinobacterial strain isolated from marine sediments of a Chilean Patagonian fjord. Morphological characterization together with antibacterial activity was assessed in various culture media, revealing a carbon-source dependent activity mainly against Gram-positive bacteria (S. aureus and L. monocytogenes). Genome mining of this antibacterial-producing bacterium revealed the presence of 26 biosynthetic gene clusters (BGCs) for secondary metabolites, where among them, $81 \%$ have low similarities with known BGCs. In addition, a genomic search in Streptomyces sp. H-KF8 unveiled the presence of a wide variety of genetic determinants related to heavy metal resistance (49 genes), oxidative stress (69 genes) and antibiotic resistance (97 genes). This study revealed that the marine-derived Streptomyces sp. H-KF8 bacterium has the capability to tolerate a diverse set of heavy metals such as copper, cobalt, mercury, chromate and nickel; as well as the highly toxic tellurite, a feature first time described for Streptomyces. In addition, Streptomyces sp. H-KF8 possesses a major resistance towards oxidative stress, in comparison to the soil reference strain Streptomyces violaceoruber A3(2). Moreover, Streptomyces sp. H-KF8 showed resistance to $88 \%$ of the antibiotics tested, indicating overall, a strong response to several abiotic stressors. The combination of these biological traits confirms the metabolic versatility of Streptomyces sp. H-KF8, a genetically well-prepared microorganism with the ability to confront the dynamics of the fiord-unique marine environment. 


\section{Genomic data mining of the marine actinobacteria}

\section{Streptomyces sp. H-KF8 unveils insights into multi-stress}

3 related genes and metabolic pathways involved in

4 antimicrobial synthesis

6 Agustina Undabarrena ${ }^{1}$, Juan Antonio Ugalde ${ }^{2,3}$, Michael Seeger $^{1}$ \& Beatriz Cámara ${ }^{1}$

$7 \quad{ }^{1}$ Laboratorio de Microbiología Molecular y Biotecnología Ambiental, Departamento de Química \&

8 Centro de Biotecnología Daniel Alkalay Lowitt, Universidad Técnica Federico Santa María, Valparaíso,

9 Chile

${ }^{2}$ Centro de Genética y Genómica, Facultad de Medicina. Clínica Alemana - Universidad del Desarrollo, Santiago, Chile

${ }^{3}$ Programa de Genética Microbiana, Facultad de Medicina, Clínica Alemana - Universidad del Desarrollo, 13 Santiago, Chile.

Corresponding Author:

16 Beatriz Cámara ${ }^{1}$

17 Avenida España 1680, Valparaíso, 2000340, Chile

18 Email address: beatriz.camara@usm.cl 


\section{Abstract}

20 Streptomyces sp. H-KF8 is an actinobacterial strain isolated from marine sediments of a Chilean

21 Patagonian fjord. Morphological characterization together with antibacterial activity was assessed in 22 various culture media, revealing a carbon-source dependent activity mainly against Gram-positive 23 bacteria (S. aureus and L. monocytogenes). Genome mining of this antibacterial-producing bacterium 24 revealed the presence of 26 biosynthetic gene clusters (BGCs) for secondary metabolites, where among them, $65 \%$ have low or no similarity with known BGCs. In addition, a genomic search in Streptomyces sp. H-KF8 unveiled the presence of a wide variety of genetic determinants related to heavy metal resistance (49 genes), oxidative stress (69 genes) and antibiotic resistance (97 genes). This study revealed that the marine-derived Streptomyces sp. H-KF8 bacterium has the capability to tolerate a diverse set of heavy metals such as copper, cobalt, mercury, chromate and nickel; as well as the highly toxic tellurite, a feature first time described for Streptomyces. In addition, Streptomyces sp. H-KF8 possesses a major resistance towards oxidative stress, in comparison to the soil reference strain Streptomyces violaceoruber A3(2). Moreover, Streptomyces sp. H-KF8 showed resistance to $88 \%$ of the antibiotics tested, indicating overall, a strong response to several abiotic stressors. The combination of these biological traits confirms the metabolic versatility of Streptomyces sp. H-KF8, a genetically wellprepared microorganism with the ability to confront the dynamics of the fiord-unique marine environment. 


\section{Introduction}

There has been a burst of genomic data in recent years due to the advances in various technologies such as next-generation sequencing. Whole genome sequencing is providing information-rich data that can hugely contribute and orientate the discovery of natural products in microorganisms. Indeed genome mining has been positioned as a fundamental bioinformatics-approach in the natural product field (McAlpine et al., 2005; Van Lanen \& Shen, 2006; Challis, 2008; Doroghazi \& Metcalf, 2013; Jensen et al., 2014; Antoraz et al, 2015; Tang et al., 2015; Katz \& Baltz, 2016). Natural products have clearly demonstrated to play a significant role in drug discovery, in fact $78 \%$ of antibiotics marketed during 1982 - 2002 originated from natural products (Peláez, 2006). Considering the year $2014,25 \%$ of the approved new chemical entities were from natural or natural-derived products (Newman \& Cragg, 2016). In natural environments, these metabolites also play important roles as signal molecules, facilitating intra- or inter-species interactions within microbial communities related to virulence, colonization, motility, stress response and biofilm formation (Romero et al., 2012).

Streptomyces are mycelium-forming bacteria with a complex developmental life cycle that includes sporulation and programmed cell death processes (Flärdh \& Buttner, 2009; Yagüe et al., 2013). Their unsurpassed richness and diversity concerning secondary metabolism pathways has made them valuable providers for bioactive molecules, being responsible for two-thirds of all known antibiotics (Bérdy, 2012). Genome mining has become a powerful tool to unveil the biotechnological potential of Streptomyces species, where biosynthetic gene clusters (BGCs) can be identified (Weber et al., 2015) and even predict the chemical core structure of the molecules. Unlike other bacteria, Streptomyces have linear chromosomes (Chen et al., 2002) and their genome sizes are within the largest in the bacterial world (Weber et al., 2003), ranging from 6.2 Mb for Streptomyces cattleya NRRL 8057 (Barbe et al., 2011) to $12.7 \mathrm{Mb}$ for Streptomyces rapamycinicus NRRL 5491 (Baranasic et al., 2013), considering complete sequenced genomes to date (Kim et al., 2015). Up to 5\% of their genomes are devoted to the synthesis of secondary metabolites (Ikeda et al., 2003). The ability to produce a wide variety of bioactive molecules is based on the fact that they contain the largest numbers of BGCs such as polyketide synthases (PKS) and non-ribosomal peptide synthetases (NRPS), or even PKS-NRPS hybrids (Challis, 2008). The genes required for secondary metabolites biosynthesis are typically clustered together (Zazopoulos et al., 2003) and are tightly regulated both by specific regulation of each product (Bibb \& Hesketh, 2009) or by pleiotropic mechanisms of regulation that can control several pathways at the same time (Martin \& Liras, 2012). Due to these interesting properties, nearly 600 species and 30,000 strains of Streptomyces have been identified (Euzéby, 2011). To date, 653 Streptomyces genome assemblies are available in GenBank database (Studholme, 2016) and this number is likely to keep increasing.

Although soil microorganisms from the Streptomyces genus have generated vast interest due to their exceptional role as antibiotic producers (Bérdy, 2012), their marine counterpart has been less explored. The marine ecosystem is highly diverse, with extreme abiotic selective pressures and immense biological diversity (Lam, 2006). In addition, many marine organisms have a sessile life style, needing chemical weapons for defense and survival (Haefner, 2003). Thus, research in natural products has been focusing on the isolation of microorganisms from corals (Hodges, Slattery \& Olson, 2012; Kuang et al., 2015; Mahmoud \& Kalendar, 2016; Pham et al., 2016), sponges (Kim, Garson \& Fuerst, 2005; Montalvo et al., 2005; Zhang et al., 2006; Jiang et al., 2007; Vicente et al., 2013; Sun et al., 2015), as well as marine sediments (Mincer et al., 2002; Magarvey et al., 2004; Jensen et al., 2005; León et al., 2007; Gontang, Fenical \& Jensen, 2007; Duncan et al., 2014; Yuan et al., 2014). In spite of all the isolation studies associated to marine actinobacteria, relatively little is known about the molecular mechanisms behind 
bacterial adaptation to marine environments. It is supposed that marine actinobacteria have adapted through the development of specific biological traits (Tian et al., 2016), which has led to hypothesize that novel species from unexplored habitats may contain unique bioactive compounds (AxenovGribanov et al., 2016). In addition, marine habitats are under a dramatic pollution increase, where heavy metals have demonstrated to be one of the most negative causing impacts in living beings. While many metals (iron, zinc, manganese, copper, cobalt, nickel, vanadium, molybdenum) are essential micronutrients for enzymes and cofactors, they still are toxic when available in high concentrations, causing adversary effects mainly by oxidative stress damage to fundamental macromolecules (Schmidt et al., 2005). In this context, marine microorganisms have developed mechanisms through molecular adaptations in order to thrive in these adverse conditions. Moreover, secondary metabolites biosynthesis are strongly influenced by the presence and concentration of certain heavy metals in Streptomyces genus (Locatelli, Goo \& Ulanova, 2016), and also oxidative stress can regulate antibiotic production (Kim et al., 2012; Beites et al., 2014) providing evidence of a molecular crosstalk response between these stressors.

In the South Pacific region, Chile has an extensive marine coast that remains mostly unexplored. Bioprospecting of actinobacteria for the discovery of novel marine-derived natural products, specifically antibiotics, has been carried out in Valparaíso Central Bay (Claverías et al., 2015) and in the Comau fjord in Northern Patagonia (Undabarrena et al., 2016a). Both sites proved to be a rich source for novel species of actinobacteria with antimicrobial properties. In this context, the genome of a selected antimicrobial-producer marine Streptomyces strain from Comau fjord was sequenced (Undabarrena et al.,2016b). In this study, we aimed to conduct a combined genomic, metabolic and physiological analysis of the marine Streptomyces sp. H-KF8 bacterium, through the further exploration of its antimicrobial activity and the genome mining of the BGCs encoded in its genome. In addition, the genetic and functional response to abiotic stressors such as oxidative stress, heavy metals and antibiotics, which may play an important role in the evolution of secondary metabolism genes, was evaluated in Streptomyces sp. H-KF8. 
113

114

115

116

117

118

119

120

121

122

123

124

125

126

127

128

129

130

131

132

133

134

135

136

137

138

139

140

141

142

143

144

145

146

147

148

149

150

151

152

153

154

155

156

157

158

\section{Methods and Materials}

\section{Bacterium selection}

Underwater samples were previously collected from marine sediments from the Marine Protected Area of the Comau fjord, in the Northern Chilean Patagonia (Undabarrena et al., 2016a). Fjords are especially attractive due to its unique biogeographic characteristics, being a deep narrow inlet with significantly eroded bottom and communication with open sea (Bredholdt et al., 2007). Comau fjord is one of the deepest; it has a high precipitation rate crucial for fresh water input; where water surface temperatures ranges between 5 and $>20^{\circ} \mathrm{C}$, sustaining a thermohaline circulation (Bustamante, 2009; Sobarzo, 2009). As microorganisms of these ecosystems may display remarkable genetic features of tolerance to the dynamics of these abiotic stressors, marine actinobacteria were isolated with several culture media and identified through 16S rRNA gene sequence (Undabarrena et al., 2016a). Antimicrobial potential was screened using two strategies, including assessing the antimicrobial activity of crude extracts derived from liquid cultures (Undabarrena et al., 2016a). Streptomyces sp. H-KF8 was selected due to its antimicrobial activities against $S$. aureus, L. monocytogenes and E. coli for whole genome sequencing, representing the first genome of Chilean marine actinobacteria (Undabarrena et al., 2016b).

\section{Phenotypic characterization}

Streptomyces sp. H-KF8 was characterized morphologically in several media agar plates: ISP1-ISP9 (Shirling \& Gottlieb, 1966), Marine Agar (MA) 2216 (Difco) and Triptic Soy Agar (TSA) (Difco N²36950). All media, with exception of MA, were prepared with artificial sea water (ASW) (Kester et al., 1967) as the strain has a specific ASW requirement for growth (Undabarrena et al., 2016). Plates were incubated at $30{ }^{\circ} \mathrm{C}$ and visible colonies appeared after 5-7 days. Microscopic images were obtained with a Leica Zoom2000 stereoscope (Arquimed), Gram-staining was performed with an optical microscope L2000A (Arquimed) with 1000X magnification, and unstained low voltage electron microscopy (LVEM) was used for high contrast images (Delong LVEM5 microscope, Universidad Andrés Bello, Chile) after 21 days of Streptomyces sp. H-KF8 growth in ISP3-ASW media (Vilos et al., 2013).

\section{Antimicrobial activity}

Antimicrobial activity was evaluated previously in ISP2 and TSA-ASW agar plates, and activity was corroborated by liquid culture derived crude extracts (Undabarrena et al., 2016a). In this study, a further evaluation of antimicrobial activity was assessed in 15 different media agar plates, to explore the relation between Streptomyces sp. H.KF8 morphology and antimicrobial activity. Various media were employed: ISP1-ISP9; MA; King B; Medium V (Marcone et al., 2010); LB-ASW; Actino Agar (Difco) and NaST21Cx (Magarvey et al., 2004), using cross-streak method as previously described (Haber and Ilan, 2014). The assay was slightly modified for marine actinobacteria by our group (Claverías et al., 2015; Undabarrena et al., 2016a). Antimicrobial activity was measured against five reference bacteria: Staphylococcus aureus NBRC 100910'; Listeria monocytogenes 07PF0776; Salmonella enterica subsp enterica $\mathrm{LT}^{\top}$; Escherichia coli FAP1 and Pseudomonas aeruginosa DSM50071 ${ }^{\top}$. Briefly, inhibition zones were seen as part of the bacterial line where the reference bacteria did not grow, and ranked qualitatively as: -, no inhibition; $+/-$, attenuated growth of target bacterium;,$+<50 \%$ growth inhibition of target bacterium (1-5 mm of the line);,$++ 50 \%$ growth inhibition of target bacterium $(6-10 \mathrm{~mm}$ of the line);,$+++>50 \%$ growth inhibition of target bacterium ( $\geq 11 \mathrm{~mm}$ of the line). All experiments were performed in duplicate, using as internal control one of the reference bacteria. 
159

202

203

204

205

206

Additionally, the double-layer method (Westerdahl et al., 1991) was employed, in order to perform a time-course assay to ascertain the days of incubation where most activity was being produced. Streptomyces sp. H-KF8 macrocolonies were incubated on ISP2-ASW, ISP3-ASW, TSA-ASW and MA agar plates. Macrocolonies were grown individually from five to 20 days on the same agar plate, and subsequently, $7 \mathrm{~mL}$ of modified-LB (7 g/L of agar instead of $15 \mathrm{~g} / \mathrm{L}$ ) with an aliquot of $100 \mu \mathrm{L}$ of an overnight pre-grown $S$. aureus bacterial culture with an $\mathrm{OD}=0.3$ was added above the macrocolonies of Streptomyces sp. H-KF8. Inhibition zones were observed after incubation of plates for $24 \mathrm{~h}$ at $37{ }^{\circ} \mathrm{C}$. If inhibition zones overlapped, the experiment was repeated on separate agar plates, where only one macrocolony in the center of the plate was incubated, as shown in Figure 2.

\section{Genome Mining and Bioinformatic analysis}

Streptomyces sp. H-KF8 whole genome sequencing was performed by Illumina and PacBio (Undabarrena et al., 2016b). Genome reads were de novo assembled using Canu (version 1.1) (Berlin et al., 2015) into 11 contigs, representing one linear chromosome of 7,684,888 bp genome. Full genome sequencing details can be found elsewhere (Undabarrena et al., 2016b). Gene calling an annotation was performed using the Prokaryotic Genome Annotation Pipeline (PGAP) at NCBI (version 3.1) (Tatusova et al., 2016). Genes were assigned to EggNOG categories (Huerta-Cepas et al., 2016) via an HMM search with HMMER3 (http://hmmer.org). Genetic determinants involved in biological traits analyzed in this report were manually established and the amino acidic signatures were validated based on domain hits through Basic Local Alignment Search Tool (BLAST) from NCBI. Also, BGCs were identified through AntiSMASH (version 3.0) online platform. Snapgene software (version 2.3.2) was used to visualize ORFs related to functional biological traits from each linear contig. Artemis software (version 16.0.0) was used to construct the graphic representation of the circular chromosome, and to assign by colors manually all the different categories of BGCs on it.

\section{Functional response to Heavy Metal(loid)s}

For metal-resistance experiments, agar plates containing filtered salts of several metal(loid) solutions were prepared. Metals were diluted to obtain the following final concentration in media plates: $\mathrm{CuSO}_{4}$ (0.25 mM, $0.5 \mathrm{mM}$ and $0.75 \mathrm{mM}$ ); $\mathrm{CoCl}_{2}(2 \mathrm{mM}, 4 \mathrm{mM}$ and $6 \mathrm{mM}) ; \mathrm{ZnSO}_{4}(50 \mathrm{mM}$ and $100 \mathrm{mM}) ; \mathrm{CdCl}_{2}$ (0.75 mM and $1.5 \mathrm{mM}) ; \mathrm{HgCl}_{2}(20 \mu \mathrm{M}, 40 \mu \mathrm{M}$ and $60 \mu \mathrm{M}) ; \mathrm{K}_{2} \mathrm{TeO}_{3}(10 \mu \mathrm{M}, 20 \mu \mathrm{M}$ and $40 \mu \mathrm{M}) ; \mathrm{K}_{2} \mathrm{CrO}_{4}$ $(10 \mu \mathrm{M}, 17 \mu \mathrm{M}$ and $20 \mu \mathrm{M}) ; \mathrm{Na}_{2} \mathrm{HAsO}_{4}(50 \mathrm{mM}$ and $100 \mathrm{mM}) ; \mathrm{NaAsO}_{3}(2.5 \mathrm{mM}$ and $5 \mathrm{mM})$ and $\mathrm{NiSO}_{4}(5$ $\mathrm{mM}, 10 \mathrm{mM}$ and $15 \mathrm{mM}$ ). Streptomyces sp. H-KF8 was evaluated after 5, 10 and 20 days of growth in TSA-ASW plates. Additionally, a special Minimal Medium (MM) used to evaluate metal resistance in Streptomyces spp. was prepared (Schmidt et al., 2009), modified with the addition of ASW. Experiment was performed with two biological replicates. Reference values for metal concentrations were decided based on metal-tolerance Streptomyces obtained from literature (Schmidt et al., 2005, 2009; Wang et al., 2006; Polti, Amoroso \& Abate, 2007). Agar plates without addition of any metals were prepared as negative controls.

\section{Functional response to Oxidative Stress}

For oxidative stress experiments, tolerance to hydrogen peroxide $\left(\mathrm{H}_{2} \mathrm{O}_{2}\right)$ at various concentrations $(0.2$ $\mathrm{M}, 0.5 \mathrm{M}, 1 \mathrm{M}, 2 \mathrm{M}$, and $4 \mathrm{M}$ ) was evaluated by directly adding $10 \mu \mathrm{L}$ of the $\mathrm{H}_{2} \mathrm{O}_{2}$ solution to a sterile paper disk positioned on a TSA-ASW agar plate where Streptomyces sp. H-KF8 was streaked out to grow as a thin lawn (Dela Cruz et al., 2010). The model strain Streptomyces violaceoruber A3(2) (DSM 40783) 
207 was used to test the tolerance response. Inhibitions areas $\left(\mathrm{cm}^{2}\right)$ were observed after 5 days of growth at $20830{ }^{\circ} \mathrm{C}$. Experiment was performed with three biological replicates, and standard deviation was 209 calculated. A statistical analysis by Student's $t$-Test was carried out considering a $p$-value $<0.01$.

\section{Functional response Antibiotics}

Susceptibility to model antibiotics of Streptomyces sp. H-KF8 was explored previously (Undabarrena et al., 2016a). However, in this report a further characterization was pursued. Streptomyces sp. H-KF8 was grown on Mueller-Hinton agar plates prepared with ASW (MH-ASW) and commercial standard disks of model antibiotics were placed above. The following antibiotics were tested: Amoxicillin $25 \mu \mathrm{M}$, Bacitracin $0.09 \mathrm{IU}$, Novobiocin $5 \mu \mathrm{g}$ and Erythromycin $15 \mu \mathrm{g}$ (LabClín); Optochin $5 \mu \mathrm{g}$ (BritaniaLab); Clindamycin $2 \mu \mathrm{g}$, Oxacillin $1 \mu \mathrm{g}$, Ciprofloxacin $5 \mu \mathrm{g}$, Ceftriaxone $30 \mu \mathrm{g}$, Chloramphenicol $30 \mu \mathrm{g}$, Penicillin $10 \mathrm{UOF}$, Cefotaxime $30 \mu \mathrm{g}$, Gentamicin $10 \mu \mathrm{g}$ and Ampicillin $10 \mu \mathrm{g}$ (Valtek). After 5 days of incubation at $30{ }^{\circ} \mathrm{C}$, radios of the inhibition halos were measured, and inhibition areas $\left(\mathrm{cm}^{2}\right)$ were calculated. Data was compared with standarized cut off values from Clinical and Laboratory Standards Institute (CLSI) from year 2016, to determine susceptibility or resistance against each antibiotic tested. Experiments were performed using three biological replicates, and standard deviation was calculated for each antibiotic. 


\section{Results}

226

\section{Phenotypic characterization}

228

229

230

231

232

233

234

235

236

237

238

239

240

241

242

243

244

245

246

247

248

249

250

251

252

253

254

255

256

257

258

259

260

261

262

Morphological analysis of Streptomyces sp. H-KF8 was carried out by strain growth in several media, containing different carbon sources (Fig 1; inset colony morphology). Growth of Streptomyces sp. H-KF8 was observed in the standard ISP1-ISP9 agar plates, although differences in growth rates and pigmentation were noticed (Fig 1A-1F). On ISP1 (yeast extract, pancreatic digest of casein), ISP2 (yeast extract, malt extract, dextrose) and ISP6 (peptone, yeast extract and iron) media, white mycelia was observed, with appearance of grayish-spores after 14 days of growth. In contrast, when Streptomyces sp. H-KF8 was grown on ISP3 (outmeal), ISP4 (soluble starch and inorganic salts), ISP5 (glycerol and asparagine) and ISP9 (glucose) media, creamy mycelia was observed, with appearance of white spores at the periphery of the colonies. In contrast, poor growth was observed in ISP7 (tyrosine) medium. A different morphology was perceived when Streptomyces sp. H-KF8 was grown on MA medium (Fig 1G). Colony size was comparatively smaller (5.06 $\pm 1.1 \mathrm{~mm}$ in ISP2 vs $3.12 \pm 0.78 \mathrm{~mm}$ in MA; $p<0.01$ ), and a dark-grey turning into black pigmentation was noticed within 5 days of growth. On TSA-ASW plates, a white mycelium was observed with no change in pigmentation over time, but with presence of exudate drops in the colony surface (Fig $1 \mathrm{H}$ ). Additionally, morphology was visualized microscopically, and typical Streptomyces structures of development such as hyphae and spores were observed (Fig 2). Exudate drops were appreciated in ISP2 medium during late growth phase (Fig 2A), spores were identified with optical microscopy (Fig 2B) and hyphae with Gram staining (Fig 2B). Moreover, the complex network of intertwined hyphae and early spore chain assemblies was observed by LVEM microscopy, which is a distinctive feature of Streptomyces genus (Fig 2D).

\section{Antimicrobial activity}

Antimicrobial activity of Streptomyces sp. H-KF8 was further characterized using agar media with different carbon sources (Table 1). In general, antimicrobial activity was more evident against Grampositive reference bacteria (S. aureus and L. monocytogenes), although inhibition against $E$. coli was also observed in most media, which is consistent with results obtained from Streptomyces sp. H-KF8 crude extracts (Undabarrena et al., 2016a). P. aeruginosa was the reference bacterium less inhibited. Among the 15 different media used, inhibition of at least one reference bacterium was noted in $87 \%$ of the media. Best media for antimicrobial activity were ISP1, ISP2, ISP6, and V media, where inhibition of four of the five reference bacteria was observed. Notably, in ISP2 medium a unique attenuation of $P$. aeruginosa growth was observed. Alternatively, a time-course assay using the double-layer method was performed to visualize the starting day of the antimicrobial activity, in four media that presented inhibition. Even though at day 5 a relatively scarce colony growth of Streptomyces sp. H-KF8 was observed in ISP2 medium, at day 6 it was possible to visualize a modest inhibition against S. aureus (Fig 3A). Yet, inhibition zone increased as incubation time for Streptomyces sp. H-KF8 extended, as shown in Fig 3B, showing a maximum halo size at day 15 (Fig $3 \mathrm{C}$ ), suggesting a tight relation between growth and antimicrobial activity which is also correlated to the carbon source of the media tested. 


\section{Bioinformatic analysis and Genome mining for BGCS}

Whole genome sequencing and genome features were previously described (Undabarrena et al.,2016b). Briefly, Streptomyces sp. H-KF8 genome was assembled into 11 contigs, with a total genome length of $7,684,888 \mathrm{bp}$, and a $\mathrm{G}+\mathrm{C}$ content of $72.1 \%$. A total of 6,574 genes are represented among 6,486 CDS, 67 tRNAs and $616 \mathrm{~S}$ rRNAs. Genes with coding sequences were grouped into COGs categories, although 808 genes remain ungrouped. Description and gene percentage of each category is depicted in Table 2. For Streptomyces sp. H-KF8, the most abundant categories were transcription (522 genes), carbohydrate transport and metabolism (362 genes), and amino acid transport and metabolism (362 genes). The Streptomyces sp. H-KF8 categorized genes were compared to the model Streptomyces violaceoruber A3(2) isolated from soil (Bentley et al., 2002) and the marine Streptomyces sp. TP-A0598 (Komaki et al., 2015), in order to observe if these features could be considered as source-derived traits (Fig 4). As there are scarce reports available on marine Streptomyces genomes that include COGs detailed annotation, Streptomyces sp. TP-A0598 is one of the few that have these characteristics, and therefore selected for comparison. While all three strains showed the same tendency in the categories previously named in terms of abundancy, differences were observed in terms of percentage in transcription and carbohydrate metabolism categories, where S. violaceoruber $\mathrm{A} 3(2)$ strain was slightly higher. On the other hand, both marine strains (Streptomyces sp. H-KF8 and Streptomyces sp. TP-A0598) showed higher number of genes related to categories of post-translational modification, protein turnover and chaperone functions, as well as in secondary metabolism and translation categories.

Secondary metabolism category comprises $2.3 \%$ of the Streptomyces sp. H-KF8 genome, being slightly higher when compared to both strains, the soil-derived S. violaceoruber $\mathrm{A} 3(2)$, and the marine-derived Streptomyces sp. TP-A0598, accounting for $1.9 \%$ and $2.0 \%$ of their genomes, respectively. A bioinformatics analysis was performed using the antiSMASH tool to detect biosynthetic gene clusters (BGCs) present in Streptomyces sp. H-KF8 that may explain the antimicrobial activity observed, and a total of 26 BGCs were detected (Undabarrena et al., 2016b). In this report, we show that the spatial distribution of the 26 BGCs are evenly allocated throughout the contigs of Streptomyces sp. H-KF8 genome (Fig 5), which were grouped into 11 different types (NRPS, PKS, hybrids, terpenes, RiPP, ectoine, melanine, siderophores, lantipeptides and butyrolatones). Furthermore, a comparison of the BGCs present in Streptomyces sp. H-KF8 with other known BGCs deposited into the MIBiG database, was performed (Table 3). In this line, Streptomyces sp. H-KF8 bears two NRPSs BGCs with very low similarity to BGCs involved in the synthesis of the lipoglycopeptide antibiotic mannopeptimycin, produced by $S$. hygroscopicus (Magarvey et al., 2006); and the streptolydigin antibiotic, which interferes with the RNA elongation by inhibition of the bacterial RNA polymerase (Olano et al., 2009), with $7 \%$ and $13 \%$ of gene similarity, respectively (Table 3). The two PKSs predicted in Streptomyces sp. H-KF8 genome corresponds to the type II spore pigment BGC showing $83 \%$ of gene similarity, and also another BGC where only $6 \%$ of gene similarity to the antibacterial kirromycin BGC from $S$. collinus Tü 365 was found (Weber et al., 2008) (Table 3). A total of eight hybrid clusters, where four of them are PKS-NRPS hybrids were also predicted, which presented low gene similarities with other known BGCs, except for one NRPS-PKS type I cluster (Table 3). In addition, other BGCs found in Streptomyces sp. KF8 included five terpenes BGCs, two lantipeptides and two ribosomally synthesized and post-translationally modified peptides (RiPPs) 
303

304

305

306

307

308

309

310

311

312

313

314

315

316

317

318

319

320

321

322

323

324

325

326

327

328

329

330

331

332

333

334

335

336

337

338

339

340

341

such as the lassopeptide and bacteriocin BGCs. In general, only six BGCs from Streptomyces sp. H-KF8 genome displayed $100 \%$ gene similarity to their most related known cluster. Examples of these consists on the BGC for the previously mentioned antibiotics moenomycin (Ostash, Saghatelian \& Walker, 2007) and albaflavenone (Zhao et al., 2008) (Table 3). Additionally, BGCs for the aromatic carotene isorenieratene, involved in anoxigenic photosynthesis in S. griseus (Krügel et al., 1999), the conserved osmolite ectoine, that may provide protection from osmotic stress (Prabhu et al., 2004; Graf et al., 2008) and the melanin pigment clusters (Guo et al., 2014; Sivaperumal, Kamala \& Rajaram, 2015) were observed with $100 \%$ similarity. Most of the BGCs (65\%) presented low similarity to BGCs of known compounds, evidencing the potential of Streptomyces sp. H-KF8 strain to produce novel bioactive molecules.

Due to the dynamics of environmental parameters from the unique isolation site of Streptomyces sp. $\mathrm{H}$ $\mathrm{KF} 8$, genome mining of pathways involved in response to abiotic stressors such as heavy metals, oxidative stress and antibiotics were also analyzed in this study, in order to unveil genetic determinants that may explain tolerance to these stressful environmental conditions.

\section{Functional response to Heavy Metals and Metalloids}

Genetic determinants involved in heavy metal-resistance in Streptomyces sp. H-KF8 were analyzed by genome mining, and at least 49 predicted genes may be playing a role in such tolerance (Fig 6A). Amongst these, the most abundant genes were related to tellurite, followed by arsenate, copper and mercury, and, to a lesser extent, chromate, nickel and cobalt tolerance (Fig 6A). Tellurite resistance genetic determinants involved seven ter $D$ genes, four ter $B$ genes, two yce $C$ genes, one ter $C$ gene and one teh $B$ gene that encodes a tellurite methyltransferase. In addition, 11 genetic determinants for arsenic tolerance were found, involving three $\operatorname{ars} C$ genes encoding arsenate reductases, two genes $\operatorname{ars} A$ encoding arsenical pump-driving ATPases, five genes ars $R$ encoding arsenical transcriptional regulators, and the arsenical resistance protein encoding gene acr3. Genetic determinants encoding for copper resistance genes, included copA and mco genes encoding multicopper oxidases, copD encoding a copper resistance protein, two genes ycnJ encoding for copper transport proteins, and two genes for the copper-sensing transcriptional regulator, csoR. Mercury resistance genes consisted in the mercury reductase encoding gene merA, and the mercury transcriptional regulator merR. In addition, the $c z c D$ and $r c n A$ genes coding for efflux pumps for cadmium, zinc, cobalt and nickel, respectively, together with the chrR gene encoding a chromate reductase, and general heavy metal tolerance such as the $h m t 1$ gene and seven genes encoding for merR-family transcriptional regulators, were also found. Considering all the genetic determinants listed above, we attempted to determine if Streptomyces sp. H-KF8 was able to grow on various metal-containing media. Streptomyces sp. H-KF8 was able to tolerate copper-, cobalt-, mercury-, tellurite-, chromate- and nickel-containing media, as shown in Fig 6B for the maximum concentrations tested. Despite the arsenic tolerance-related genes present in Streptomyces sp. H-KF8 genome, comprising $27 \%$ of the total number of metal-related genes, no evident growth of Streptomyces sp. H-KF8 was perceived in this metalloid-containing medium, even in the two different toxic forms of arsenic tested: arsenate and arsenite. Also, no growth was observed in media containing cadmium or zinc. 
343 A significant amount of genes (69 genes) that may participate in the detoxification of reactive oxygen species (ROS) were found within the Streptomyces sp. H-KF8 genome (Fig 7A). Genes for mycothiol biosynthesis (20 genes), thioredoxin and thioredoxin reductases system (11 genes), alkyl hydroperoxide reductases (nine genes), glutaredoxin and glutathione peroxidase system (four genes), catalases (three genes), and superoxide dismutases (three genes), among others, were identified (Fig 7A). Interestingly, genes involved in osmotic stress detoxification of chlorinated and brominated compounds such as three bpo genes encoding for bromoperoxidases, one cpo gene encoding for a chloroperoxidase and one gene encoding for a chlorite dismutase were also present in Streptomyces sp. H-KF8 genome (Fig 7A). Concerning transcriptional regulators controlling the redox balance, transcriptional factors from perR, rex, lys $R$ and sox $R$ families, were also present. Due to an important genetic content of oxidative stress related genes, response of Streptomyces sp. $\mathrm{H}-\mathrm{KF} 8$ to the toxic $\mathrm{H}_{2} \mathrm{O}_{2}$ was tested, and compared to the model streptomycete $S$. violaceoruber $\mathrm{A} 3(2)$. At various $\mathrm{H}_{2} \mathrm{O}_{2}$ concentrations, Streptomyces sp. $\mathrm{H}-\mathrm{KF} 8$ displayed smaller susceptibility areas against the toxic, in comparison with S. violaceoruber A3(2) (Fig 7B and $7 \mathrm{C}$, respectively). A significant difference of the suceptibility areas among the two strains was observed at concentrations of $1 \mathrm{M}, 2 \mathrm{M}$ and $4 \mathrm{M}$ of $\mathrm{H}_{2} \mathrm{O}_{2}$, indicating a major resistance response of Streptomyces sp. H-KF8 towards $\mathrm{H}_{2} \mathrm{O}_{2}$ toxicity (Fig 7D).

\section{9}

360

361

362

363

364

365

366

367

368

369

370

371

372

373

374

375

376

\section{Functional response to Antibiotics}

Antibiotic-producing Streptomyces strains usually encode resistance genes within their BGCs to protect themselves against the noxious action of the synthetized compound (Zotchev, 2014). In this line, resistance of Streptomyces sp. H-KF8 to commercial antibiotics with different biological targets was explored. Genome mining revealed more than 90 genes that could be involved in antibiotic resistance. The most abundant genes encode for bleomycin resistance proteins (24 genes). Specific resistance genes related to modification and inactivation of antibiotics such as aminoglycoside phosphotransferases (eight genes), $\beta$-lactamases (three genes), metallo- $\beta$-lactamases (three genes), and one gene for erythromycin esterase and penicillin amidase, respectively, were identified (Fig 8A). In addition, genes for efflux of toxic compounds including multidrug resistance proteins (20 genes), daunorubicin/doxorubicin $A B C$ transporter permeases (15 genes), multidrug $A B C$ transporters (seven genes) and one gene encoding for a multidrug MFS transporter, were detected (Fig 8A). Among the transcriptional regulators, the TetR-family transcriptional regulators were the most abundant, with 10 genes. Also, the marR-family transcriptional regulator and three marR genes encoding for multiple antibiotic resistance proteins were identified (Fig $8 \mathrm{~A}$ ). In the functional assay against 16 different antibiotics tested, Streptomyces sp. H-KF8 exhibited an $88 \%$ of resistance-response, being susceptible to only two antibiotics: novobiocin, which targets the DNA gyrase, and gentamicin, which inhibits protein synthesis by irreversibly binding to the $30 \mathrm{~S}$ subunit of the bacterial ribosome (Fig 8B). 
377

378

379

380

381

382

383

384

385

386

387

388

389

390

391

392

393

394

395

396

397

398

399

400

401

402

403

404

405

406

407

408

409

410

411

412

413

414

415

416

\section{Discussion}

In this report, phenotypic analysis of Streptomyces sp. H-KF8 in several agar media was assessed, revealing in general one week of incubation time to obtain colonies and two weeks for sporulation; although growth rates, sporulation rates and pigmentation differs throughout the different media used. Antimicrobial production in Streptomyces sp. H-KF8 was enhanced in late growth phase ( $>10$ days) and favoured in media where sporulation was observed. Streptomyces genus is characterized for slow growth and a complex developmental life cycle (Flärdh \& Buttner, 2009). Physiological differentiation is tightly linked to secondary metabolism and hence, sporulation capacities of Streptomyces might enhance the discovery of new compounds (Chater, 2013; Kalan et al., 2013; Zhu et al., 2015). In addition, antibiotics synthesis is regulated by environmental nutrients, such as carbon sources. Media carbon source has an important effect on antibiotic production, being demonstrated that when bacteria are grown with a preferred carbon source, secondary metabolism seems repressed (Sánchez et al., 2010). This may explain the differences in inhibition patterns observed for the Streptomyces sp. H-KF8 antagonistic assays displayed in the various media tested, showing a maximum inhibition halo against $S$. aureus after 15 days of incubation. Due to the interesting antibacterial activity of Streptomyces sp. HKF8, its whole-genome was sequenced and previously reported (Undabarrena et al., 2016b). Thus, in this study an extended genome analysis for Streptomyces sp. H-KF8 was performed, in order to gain insights into the mechanisms by which it displays antibiotic biosynthesis and resistance to multiple stressors.

Genome mining has been used in various fields to describe the exploitation of genomic information for the discovery of new processes, targets and products (Challis, 2008). Through genome sequencing and bioinformatic analysis using antiSMASH platform (Medema et al., 2011; Blin et al., 2013; Weber et al., 2015), it is possible to address the secondary metabolic potential of a strain by identification of its biosynthesis gene clusters (BGCs) (Iftime et al., 2016). A total of 26 BGCs were previously detected in Streptomyces sp. H-KF8 genome (Undabarrena et al., 2016b). In this report, an extended genetic analysis including the distribution of these BGCs along Streptomyces sp. H-KF8 genome was determined and comparison with known BGCs from the Minimum Information about a Biosynthetic Gene cluster (MIBiG) database, which compiles a total of 1,170 experimentally characterized known gene clusters (Medema et al., 2015) was aimed. Streptomyces sp. H-KF8 BGCs include two PKSs, two NRPSs and four hybrid PKSNRPS, four other hybrids, five terpenes, two lantipeptides, one bacteriocin, lassopeptide, siderophore, butyrolactone, ectoine, melanin, and one with unknown classification. Notably, Streptomyces sp. H-KF8 presented only six BGCs with $100 \%$ similarity to a known cluster; suggesting that most secondary metabolites produced by Streptomyces sp. H-KF8 are yet to be elucidated, and can contribute to the discovery of novel natural products. In this context, genome mining has proven to be a fundamental tool for genome-based natural product discovery (Jensen et al., 2014), and has guided the discovery of novel natural products from several marine actinobacteria (Gulder \& Moore, 2010; Tang et al., 2015b). Among these are the aromatic polyketide angucyclinone antibiotic (Zhang et al., 2012) and polyene macrolides with antifungal activity (Tang et al., 2015a). Moreover, marine Streptomyces metabolites are produced by different metabolic pathways in comparison to their terrestrial counterparts (Li et al., 2011; Lee et al., 2014; Barakat \& Beltagy, 2015). These metabolites emerge as a result of the unique and dynamic conditions of the ocean, such as high hydrostatic pressure, low temperature, variation in salinity, and 
417

418

419

420

421

422

423

424

425

426

427

428

429

430

431

432

433

434

435

436

437

438

439

440

441

442

443

444

445

446

447

448

449

450

451

452

453

454

455

456

depletion of micronutrients proper of the marine environment (Das, Lyla \& Khan, 2006; Lam, 2006; de Carvalho \& Fernandes, 2010). Despite that marine adaptations are scarcely studied, recent comparative genomics of marine-derived Streptomyces unveiled an enrichment in TrK and BCCT transporters, along with the observation that their genomes are generally smaller in size and have a slightly higher GC content in comparison to Streptomyces from other environmental sources (Tian et al., 2016). Streptomyces sp. H-KF8 genome is consistent with these findings, holding distinctive biological and genomic signatures acknowledged for marine Streptomyces strains. Therefore, its metabolite biosynthesis may be under marine abiotic selective pressures, hence modulating secondary metabolism production.

Comparative genomics encompassing completely sequenced Streptomyces obtained from several isolation sources revealed that the most abundant COG categories were transcription (K), followed by carbohydrate metabolism (G) and amino acid metabolism (E) (Kim et al., 2015). This is in agreement with the most abundant categories found in the Streptomyces sp. H-KF8 genome, which also could explain the versatility of Streptomyces sp. H-KF8 to grow in several media with different carbon sources. Furthermore, in marine-derived Streptomyces, a higher proportion of genes belonging to the COG categories of translation $(\mathrm{J})$ and post-translational modification, protein turnover and chaperones (O) was observed (Tian et al., 2016). Accordingly, the (J) and (O) COGs categories were also overrepresented in both marine strains analyzed, Streptomyces sp. H-KF8 and Streptomyces sp. TP-A0598 (Komaki et al., 2015), in comparison to the terrestrial Streptomyces violaceoruber A3(2) (Bentley et al., 2002). This may indicate an important role of protein metabolism in marine environments, probably due to the active responses against abiotic stressors and the dynamics that microorganisms have to overcome to survive in these extreme ecosystems. In addition, our analysis showed an increase in the categories of cell cycle control, cell division, chromosome portioning (D), secondary metabolism (Q) and defense mechanisms (V), for both marine strains in comparison to Streptomyces violaceoruber A3(2). Percentage of the COG category for defense mechanisms (V) in Streptomyces sp. H-KF8 was interestingly higher $(2,81 \%)$ than in Streptomyces sp. TP-A0598 (1,8\%), and comparatively similar with what was observed for deep-sea bacteria (3,0 \%) (Qin et al., 2011). As the defense mechanism category includes genes for resistance to heavy metals, osmotic and oxidative stress as well as antibiotics, the functionality of these biological traits was evaluated for Streptomyces sp. H-KF8, and notably, an important resistance to these multiple stressors was evidenced.

Environmental pollution by heavy metals can arise due to anthropogenic and/or geogenic sources. Although metal-resistant strains isolated from contaminated areas have been described (Amoroso et al., 2001; Schmidt et al., 2005, 2009; Polti, Amoroso \& Abate, 2007; Albarracin et al., 2008; Haferburg et al., 2008; Siñeriz, Kothe \& Abate, 2009; Lin et al., 2011; El Baz et al., 2015), there is limited information about the physiology of Streptomyces in presence of environmental metal pollutants. Due to the naturally high concentrations of certain heavy metals in Chilean northern Patagonia (Guevara et al., 2004; Revenga et al., 2012; Hermanns \& Biester, 2013) product of the highly active seismic and volcanic activity (Pantoja, Luis Iriarte \& Daneri, 2011), the ability of Streptomyces sp. H-KF8 to grow in several metal(loid)s supplemented media was evaluated. Surprisingly, resistance to copper, cobalt, mercury, tellurite, chromate and nickel was revealed. 
457

458

459

460

461

462

463

464

465

466

467

468

469

470

471

472

473

474

475

476

477

478

479

480

481

482

483

484

485

486

487

488

489

490

491

492

493

494

495

496

Interestingly, the most abundant genes in Streptomyces sp. H-KF8 were related to tellurite resistance, involving the tellurite methyltransferase (encoded by tehB) and several tellurite resistance genes (terB, $\operatorname{ter} C$, terD, yceC). Although the ter operon has been described previously (Taylor, 1999), specification of its mechanism of action remains obscure (Chasteen et al., 2009). Mainly, it has been shown that tellurite detoxification is via enzymatic reduction by several flavoprotein-mediated non-specific metabolic enzymes (Arenas-Salinas et al., 2016), or by non-enzymatic mechanisms mediated by intracellular thiols like glutathione (Turner et al., 2001). Either way, tellurite reduction generates oxygen reactive species (ROS), especially superoxide anion $\left(\mathrm{O}_{2}^{-}\right)$, which is deleterious to fundamental cell macromolecules producing protein oxidation, lipid peroxidation and DNA damage (Pérez et al., 2007; Tremaroli, Fedi \& Zannoni, 2007). Surprisingly, Streptomyces sp. H-KF8 did not show black pigmentation after tellurite exposure, which is a distinctive phenotype that indicates tellurite reduction to elemental tellurium (Taylor, 1999), suggesting that other mechanisms of resistance could be involved in Streptomyces sp. $\mathrm{H}$ KF8. To our knowledge, this is the first tellurite-resistant Streptomyces strain described so far.

Additionally, resistance to mercury at a concentration of $60 \mu \mathrm{M}$ was observed for Streptomyces sp. $\mathrm{H}$ KF8. In general, bacteria capable of resisting mercury above $20 \mu \mathrm{M}$, should possess specific detoxification systems, as mercury is one of the most toxic elements on earth and produces several health concerns for macroorganisms (Das, Dash \& Chakraborty, 2016). In bacteria, two different resistance operons are known, the basic narrow-spectrum mer operon merRTPA for inorganic mercury, and the broad-spectrum operon that additionally contains merB, which provides protection against organo-mercurial compounds (Barkay, Miller \& Summers, 2003). In addition, it was recently demonstrated that mercury resistance mechanisms could also be involved in tellurite cross-resistance (Rodriguez-Rojas et al., 2015). Studies in Streptomyces includes S. lividans 132, that carries two divergently transcribed operons named merAB and merRTP in the chromosome (Sedlmeier \& Altenbuchner, 1992; Brünker et al., 1996; Rother, Mattes \& Altenbuchner, 1999), and two Streptomyces spp. strains isolated from estuarine sediments where these genes were also observed in giant linear plasmids (Ravel, Schrempf \& Hill, 1998; Ravel et al., 2000). Interestingly, the genetic operons mentioned above were not detected in Streptomyces sp. H-KF8, despite the fact that a mercury-resistance phenotype was evidenced. Instead, the presence of two mercury-related genes, the transcriptional regulator merR and the mercuric reductase merA, may be playing a role in such resistance. MerA is a flavoprotein NADPH-dependent enzyme responsible for the reduction of mercury(II) to the elemental and less toxic volatile mercury(0) (Barkay, Miller \& Summers, 2003). Similarly, evidence of functional operons conformed either by merA or merRA have been previously reported in archaea (Boyd \& Barkay, 2012).

However, no evident growth was observed in the presence of arsenate or arsenite, although Streptomyces sp. H-KF8 bears at least 11 genetic determinants that could involved in its detoxification. In general, the arsenic resistance operon consists of $\operatorname{ars} R A B C D$ genes, where ars $C$ encodes for an arsenate reductase that converts arsenate to arsenite, which is then exported through the Ars $A B$ ATPase-efflux pump. In Streptomyces sp. H-KF8, ars A, ars $C$ and $\operatorname{ars} R$ genes are present, but lack the $\operatorname{ars} B$ gene, which encodes an arsenite antiporter, crucial for anchoring ArsA to the inner membrane with concomitant detoxification of arsenite. Absence of the $\operatorname{ars} B$ gene may explain the sensitivity of 
497

498

499

500

501

502

503

504

505

506

507

508

509

510

511

512

513

514

515

516

517

518

519

520

521

522

523

524

525

526

527

528

529

530

531

532

533

534

535

536

Streptomyces sp. H-KF8 towards these toxics. Arsenic resistance genes are generally widespread amongst both Gram-positive and Gram-negative bacteria, reflecting its broad distribution in the environment (Silver \& Phung, 2005). In fact, these genes were also conserved in several marine streptomycetes from the South China Sea (Tian et al., 2016).

Streptomyces sp. H-KF8 displayed a notorious copper-resistant phenotype, concordant with the detection of three copA genes encoding for multicopper oxidases that may be responsible for the oxidation of $\mathrm{Cu}(\mathrm{I})$ to its less toxic form $\mathrm{Cu}(\mathrm{II})$ (Hobman \& Crossman, 2014). Copper is an essential metal for living beings, but is extremely toxic at higher concentrations (Gaetke \& Chow, 2003). Moreover, Chile is the major copper-producing country in the world, due its geological nature (Wacaster, 2015). Hence, the widespread of copper resistant genetic determinants that has been demonstrated in Chilean marine sediments (Besaury et al., 2013) is expected.

Resistance to nickel and cobalt in Streptomyces sp. H-KF8 might be given by the rcnA gene that participates in the efflux system of these metals. Highly nickel- and cobalt-resistant Streptomyces were found in an acid mine drainage, where growth in media containing up to $10 \mathrm{mM}$ nickel(II) or $3 \mathrm{mM}$ cobalt(II) was observed (Schmidt et al., 2005). In this report, Streptomyces sp. H-KF8 was able to grow even at higher concentrations: $15 \mathrm{mM}$ nickel(II) and $6 \mathrm{mM}$ cobalt(II), respectively. Furthermore, chromate toxicity $(20 \mathrm{mM})$ might be overcome in Streptomyces sp. H-KF8 due to the presence of the chrR gene encoding a chromate reductase involved in the enzymatic reduction of chromate to the less harmful chromite cation (Das, Dash \& Chakraborty, 2016). Previously reported Streptomyces chromateresistant strains isolated from sugar cane plant were able to grow in $17 \mathrm{mM}$, where also chromateremoving activity was demonstrated (Polti, Amoroso \& Abate, 2007).

Metal exposure and adverse abiotic environmental factors produces a general condition of oxidative stress in microorganisms. As oxidative stress is hazardous for fundamental macromolecules, bacteria have evolved several mechanisms to protect themselves from these environmental stresses. In Streptomyces sp. H-KF8, an exceptional response to several concentrations of $\mathrm{H}_{2} \mathrm{O}_{2}$ was observed, compared to the model Streptomyces violaceoruber $\mathrm{A} 3(2)$ which was more susceptible towards the toxic. Consequently, a wide number of genetic determinants related to ROS response were present in the Streptomyces sp. H-KF8 genome. Remarkably, a high number of thioredoxins (trx) and alkyl hydroperoxide reductases ( $a h p)$ genes (nine of each) were found in Streptomyces sp. H-KF8, in comparison with Streptomyces violaceoruber $\mathrm{A} 3(2)$ where five and one genes were described, respectively. The $a h p$ and trx are fundamental $\mathrm{H}_{2} \mathrm{O}_{2}$-inducible genes that encodes for enzymes known to participate in the bacterial response to oxidative stress, which are regulated by oxyR in E. coli (Storz \& Imlay, 1999; Seaver \& Imlay, 2001; Chiang \& Schellhorn, 2012). The oxyR regulon is not present in Streptomyces sp. H-KF8, but instead two copies of the perR regulator fulfill its role in Gram-positive bacteria (Ricci et al., 2002; Dubbs \& Mongkolsuk, 2012). Also, the ohrR transcriptional regulator that senses organic peroxide ( $\mathrm{ROOH}$ ) and sodium hypochlorite ( $\mathrm{NaOCl}$ ) (Dubbs \& Mongkolsuk, 2012) was found in Streptomyces sp. H-KF8. In addition, several genes regulated by the soxR transcriptional regulatory system such as glutaredoxin and glutathione peroxidase, superoxide dismutases (sod), catalases (kat) and thioredoxin reductases were recognized in Streptomyces sp. H-KF8 genome, which overall may be accounting for it resistance through $\mathrm{H}_{2} \mathrm{O}_{2}$ exposure. Even more, the chromate reductase 
537 (chrR) previously mentioned, could also provide additional protection against $\mathrm{H}_{2} \mathrm{O}_{2}$ (Das, Dash \& 538 Chakraborty, 2016). Interestingly, unusual genes encoding for bromoperoxidases, chloroperoxidases and 539 chlorite dismutases, involved in osmotic stress detoxification of brominated and chlorinated toxic compounds which are abundant in the marine environments (Sander et al., 2003; Bouwman et al., 2012), were also present in Streptomyces sp. H-KF8 genome. On the other hand, Streptomyces violaceoruber $\mathrm{A} 3(2)$ possess only one chloroperoxidase, suggesting that this might represent another marine adaptation trait for Streptomyces sp. H-KF8. Osmotic and oxidative stress response seems to be regulated via a network of sigma factors in Streptomyces violaceoruber A3(2), that controls the activation of several oxidative defense proteins, chaperones and systems that provide osmolytes and mycothiol (Lee et al., 2005). Consistently, a high amount of genes for mycothiol biosynthesis was identified in Streptomyces sp. H-KF8. Mycothiol is the major low-molecular-weight thiol present in actinobacteria, and serves as a buffer to advert disulfide stress, in complement of the enzymatic system presented above (Buchmeier \& Fahey, 2006; den Hengst \& Buttner, 2008).

Recently, evidence of heavy metal driving co-selection of antibiotic resistance in both natural environments (Seiler \& Berendonk, 2012) and contaminated ones (Li, Li \& Zhang, 2015; Henriques et al., 2016) have been reported. In this line, isolation of Streptomyces with both metal and antibiotic coresistances have been described (Van Nostrand et al., 2007). In addition, co-evolution of resistance within closely related antibiotic-producing bacteria has been demonstrated for Streptomyces (Laskaris et al., 2010). Hence, the antibiotic response against pharmaceutical compounds was investigated in Streptomyces sp. H-KF8, and resistance was observed to all antibiotics tested, with exception of gentamicin and novobiocin. Resistance to almost all antibiotics tested, could be due to the presence of multiple BGCs with different mode of action. A typical BGC cluster that produces a bioactive compound is generally coupled to its corresponding resistance gene (Zotchev, 2014). The phenomena of widespread distribution antibiotic resistance genes in natural environments is consequence of improper use of antibiotics in medical treatment, as well as by an indiscriminate use in agriculture, livestock and aquaculture (Brown et al., 2006). Phenomena such as the grasshopper effect may also contribute to the rapid transport of toxics around the globe through atmospheric and oceanic currents (Sadler \& Connell, 564 2012).

Overall, our study shows the response of a marine Streptomyces sp. H-KF8 against several abiotic stressors such as heavy metals, oxidative stress and antibiotics, along with the genome mining of the biosynthetic gene clusters that could be involved in the antimicrobial activity observed. Altogether,

568 these biological features may enable Streptomyces sp. H-KF8 to thrive in the complex fjord marine 569 environment. 


\section{Bibliography}

572

573

574

575

576

577

578

579

580

581

582

583

584

585

586

587

588

589

590

591

592

593

594

595

596

597

598

599

600

601

602

603

604

605

606

607

608

609

610

611

612

613

614

Albarracin VH., Avila AL., Amoroso MJ., Abate CM. 2008. Copper removal ability by Streptomyces strains with dissimilar growth patterns and endowed with cupric reductase activity. FEMS Microbiology Letters 288:141-148. DOI: 10.1111/j.15746968.2008.01335.x.

Amoroso MJ., Castro GR., Durán a., Peraud O., Oliver G., Hill RT. 2001. Chromium accumulation by two Streptomyces spp. isolated from riverine sediments. Journal of industrial microbiology \& biotechnology 26:210-215. DOI: 10.1038/sj.jim.7000112.

Antoraz S., Santamaria RI., Diaz M., Sanz D., Rodriguez H. 2015. Toward a new focus in antibiotic and drug discovery from the Streptomyces arsenal. Frontiers in Microbiology 6:1-8. DOI: 10.3389/fmicb.2015.00461.

Arenas-Salinas M., Vargas J., Morales W., Pinto C., Muñoz P., Cornejo FA., Pugin B., Sandoval J., Diaz W., Muñoz-Villagrán C., Rodríguez FJ., Morales E., Vásquez CC., Arenas F. 2016. Flavoprotein-mediated tellurite reduction: structural basis and applications to the synthesis of tellurium-containing nanostructures. Frontiers in Microbiology 7:1160. DOI: 10.3389/FMICB.2016.01160.

Axenov-Gribanov D V., Voytsekhovskaya I V., Tokovenko BT., Protasov ES., Gamaiunov S V., Rebets Y V., Luzhetskyy AN., Timofeyev MA. 2016. Actinobacteria isolated from an underground lake and moonmilk speleothem from the biggest conglomeratic karstic cave in Siberia as sources of novel biologically active compounds. PLoS ONE 11:1-12. DOI: 10.1371/journal.pone.0149216.

Barakat KM., Beltagy EA. 2015. Bioactive phthalate from marine Streptomyces ruber EKH2 against virulent fish pathogens. Egyptian Journal of Aquatic Research 41:49-56. DOI: 10.1016/j.ejar.2015.03.006.

Baranasic D., Gacesa R., Starcevic A., Zucko J., Blazic M., Horvat M., Gjuracic K., Fujs S., Hranueli D., Kosec G., Cullum J., Petkovic H. 2013. Draft genome sequence of Streptomyces rapamycinus strain NRRL 5491, the producer of the immunosuppressant rapamycin. Genome Announcement 1:e00581-13. DOI: 10.1099/ijs.

Barbe V., Bouzon M., Mangenot S., Badet B., Poulain J., Segurens B., Vallenet D., Marliere P., Weissenbach J. 2011. Complete genome sequence of Streptomyces cattleya NRRL 8057, a producer of antibiotics and fluorometabolites. Journal of Bacteriology 193:5055-5056. DOI: 10.1128/JB.05583-11.

Barkay T., Miller SM., Summers AO. 2003. Bacterial mercury resistance from atoms to ecosystems. FEMS Microbiology Reviews 27:355-384. DOI: 10.1016/S0168-6445(03)00046-9.

El Baz S., Baz M., Barakate M., Hassani L., El Gharmali A., Imziln B. 2015. Resistance to and accumulation of heavy metals by actinobacteria isolated from abandoned mining areas. Scientific World Journal 2015. DOI: 10.1155/2015/761834.

Beites T., Rodríguez-García A., Moradas-Ferreira P., Aparicio JF., Mendes M V. 2014. Genome-wide analysis of the regulation of pimaricin production in Streptomyces natalensis by reactive oxygen species. Applied Microbiology and Biotechnology 98:2231-2241. DOI: 10.1007/s00253-013-5455-z.

Bentley S., Chater K., Cerdeño-Tárraga A-M., Challis GL., Thomson NR., James KD., Harris DE., Quail M a., Kieser H., Harper D., Bateman A., Brown S., Chandra G., Chen CW., Collins M., Cronin A., Fraser A., Goble A., Hidalgo J., Hornsby T., Howarth S., Huang C-H., Kieser T., Larke L., Murphy L., Oliver K., O’Neil S., Rabbinowitsch E., Rajandream M., Rutherford K., Rutter S., Seeger K., Saunders D., Sharp S., Squares R., Squares S., Taylor K., Warren T., Wietzorrek A., Woodward J., Barrell BG., Parkhill J., Hopwood D a. 2002. Complete genome sequence of the model actinomycete Streptomyces coelicolor A3(2). Nature 417:141-147. DOI: 10.1038/417141a.

Bérdy J. 2012. Thoughts and facts about antibiotics: Where we are now and where we are heading. The Journal of Antibiotics 65:441-441. DOI: 10.1038/ja.2012.54.

Berlin K., Koren S., Chin C-S., Drake JP., Landolin JM., Phillippy AM. 2015. Assembling large genomes with single-molecule sequencing and locality-sensitive hashing. Nature biotechnology 33:623-630. DOI: 10.1038/nbt.3238.

Besaury L., Bodilis J., Delgas F., Andrade S., De la Iglesia R., Ouddane B., Quillet L. 2013. Abundance and diversity of copper resistance genes cusA and copA in microbial communities in relation to the impact of copper on Chilean marine 
sediments. Marine Pollution Bulletin 67:16-25. DOI: 10.1016/j.marpolbul.2012.12.007.

616

617

618

619

620

621

622

623

624

625

626

627

628

629

630

631

632

633

634

635

636

637

638

639

640

641

642

643

644

645

646

647

648

649

650

651

652

653

654

655

656

Bibb M., Hesketh A. 2009. Analyzing the Regulation of Antibiotic Production in Streptomycetes. Elsevier Inc. DOI: 10.1016/S0076-6879(09)04804-6.

Blin K., Medema MH., Kazempour D., Fischbach MA., Breitling R., Takano E., Weber T. 2013. antiSMASH 2.0--a versatile platform for genome mining of secondary metabolite producers. Nucleic acids research 41:204-212. DOI: 10.1093/nar/gkt449.

Bouwman H., Kylin H., Choong Kwet Yive NS., Tatayah V., L??ken K., Utne Skaare J., Polder A. 2012. First report of chlorinated and brominated hydrocarbon pollutants in marine bird eggs from an oceanic Indian Ocean island. Environmental Research 118:53-64. DOI: 10.1016/j.envres.2012.05.009.

Boyd ES., Barkay T. 2012. The mercury resistance operon: From an origin in a geothermal environment to an efficient detoxification machine. Frontiers in Microbiology 3:1-13. DOI: 10.3389/fmicb.2012.00349.

Bustamante, M.S., 2009. The southern Chilean fjord region: oceanographic aspects, in: Marine Benthic Fauna of Chilean Patagonia. pp. 53-60.

Bredholdt, H., Galatenko, O. a, Engelhardt, K., Fjaervik, E., Terekhova, L.P., Zotchev, S.B., 2007. Rare actinomycete bacteria from the shallow water sediments of the Trondheim fjord, Norway: isolation, diversity and biological activity. Environ. Microbiol. 9, 2756-64. doi:10.1111/j.1462-2920.2007.01387.x

Brown KD., Kulis J., Thomson B., Chapman TH., Mawhinney DB. 2006. Occurrence of antibiotics in hospital, residential, and dairy effluent, municipal wastewater, and the Rio Grande in New Mexico. Science of the Total Environment 366:772-783. DOI: 10.1016/j.scitotenv.2005.10.007.

Brünker P., Rother D., Sedlmeier R., Klein J., Mattes R., Altenbuchner J. 1996. Regulation of the operon responsible for broadspectrum mercury resistance in Streptomyces lividans 1326. Molecular and General Genetics 251:307-315. DOI: $10.1007 / \mathrm{s} 004380050171$.

Buchmeier N., Fahey RC. 2006. The mshA gene encoding the glycosyltransferase of mycothiol biosynthesis is essential in Mycobacterium tuberculosis Erdman. FEMS Microbiology Letters 264:74-79. DOI: 10.1111/j.1574-6968.2006.00441.x.

de Carvalho CCCR., Fernandes P. 2010. Production of metabolites as bacterial responses to the marine environment. Marine drugs 8:705-27. DOI: 10.3390/md8030705.

Challis GL. 2008. Mining microbial genomes for new natural products and biosynthetic pathways. Microbiology 154:1555-1569. DOI: $10.1099 /$ mic.0.2008/018523-0.

Chasteen TG., Fuentes DE., Tantalean JC., Vasquez CC. 2009. Tellurite: history, oxitative stress, and molecular mechanisms of resistance. FEMS Microbiol Rev 33:820-832. DOI: 10.1111/j.1574-6976.2009.00177.x.

Chater KF. 2013. Curing baldness activates antibiotic production. Chemistry and Biology 20:1199-1200. DOI: 10.1016/j.chembiol.2013.10.001.

Chen CW., Huang CH., Lee HH., Tsai HH., Kirby R. 2002. Once the circle has been broken: Dynamics and evolution of Streptomyces chromosomes. Trends in Genetics 18:522-529. DOI: 10.1016/S0168-9525(02)02752-X.

Chiang SM., Schellhorn HE. 2012. Regulators of oxidative stress response genes in Escherichia coli and their functional conservation in bacteria. Archives of Biochemistry and Biophysics 525:161-169. DOI: 10.1016/j.abb.2012.02.007.

Claverías FP., Undabarrena A., González M., Seeger M., Cámara B. 2015. Culturable diversity and antimicrobial activity of Actinobacteria from marine sediments in Valparaíso bay, Chile. Frontiers in Microbiology 6:1-11. DOI: 10.3389/fmicb.2015.00737.

Dela Cruz R., Gao Y., Penumetcha S., Sheplock R., Weng K., Chander M. 2010. Expression of the Streptomyces coelicolor SoxR regulon is intimately linked with actinorhodin production. Journal of Bacteriology 192:6428-6438. DOI: 10.1128/JB.00916-10.

Das S., Dash HR., Chakraborty J. 2016. Genetic basis and importance of metal resistant genes in bacteria for bioremediation of 
657

658

659

660

661

662

663

664

665

666

667

668

669

670

671

672

673

674

675

676

677

678

679

680

681

682

683

684

685

686

687

688

689

690

691

692

693

694

695

696

contaminated environments with toxic metal pollutants. Applied Microbiology and Biotechnology 100:2967-2984. DOI: 10.1007/s00253-016-7364-4.

Das S., Lyla PS., Khan SA. 2006. Marine microbial diversity and ecology : importance and future perspectives. Current Science 90:1325-1335.

Doroghazi JR., Metcalf WW. 2013. Comparative genomics of actinomycetes with a focus on natural product biosynthetic genes. BMC genomics 14:611. DOI: 10.1186/1471-2164-14-611.

Dubbs JM., Mongkolsuk S. 2012. Peroxide-sensing transcriptional regulators in bacteria. Journal of Bacteriology 194:5495-5503. DOI: 10.1128/JB.00304-12.

Duncan KR., Haltli B., Gill KA., Correa H., Berrué F., Kerr RG. 2014. Exploring the diversity and metabolic potential of actinomycetes from temperate marine sediments from Newfoundland, Canada. Journal of Industrial Microbiology and Biotechnology 42:57-72. DOI: 10.1007/s10295-014-1529-x.

Ettlinger L., Corbaz R., Hütter R. 1958. Zur Systematik der Actinomyceten 4. Eine Arteneinteilung der Gattung Streptomyces Waksman and Henrici. Archiv für Mikrobiologie 31:326-358. DOI: 10.1017/CBO9781107415324.004.

Euzéby J. 2011. Notification that new names and new combinations have appeared in volume 59, part 8, of the IJSEM. International journal of systematic and evolutionary microbiology 61:477-478. DOI: 10.1099/ijs.0.019158-0.

Felsenstein J. 1981. Evolutionary trees from DNA sequences: A maximum likelihood approach. Journal of Molecular Evolution 17:368-376. DOI: 10.1007/BF01734359.

Felsenstein J. 1985. Confidence Limits on Phylogenies: An Approach Using the Bootstrap. Evolution 39:783-791.

Flärdh K., Buttner MJ. 2009. Streptomyces morphogenetics: dissecting differentiation in a filamentous bacterium. Nature Reviews Microbiology 7:36-49. DOI: 10.1038/nrmicro1968.

Gaetke LM., Chow CK. 2003. Copper toxicity, oxidative stress, and antioxidant nutrients. Toxicology 189:147-163. DOI: 10.1016/S0300-483X(03)00159-8.

Gontang E., Fenical W., Jensen P. 2007. Phylogenetic diversity of gram-positive bacteria cultured from marine sediments. Applied and environmental microbiology 73:3272-82. DOI: 10.1128/AEM.02811-06.

Graf R., Anzali S., Buenger J., Pfluecker F., Driller H. 2008. The multifunctional role of ectoine as a natural cell protectant. Clinics in Dermatology 26:326-333. DOI: 10.1016/j.clindermatol.2008.01.002.

Guevara SR., Bubach D., Vigliano P., Lippolt G., Arribére M. 2004. Heavy metal and other trace elements in native mussel Diplodon chilensis from Northern Patagonia Lakes, Argentina. Biological trace element research 102:245-263. DOI: 10.1385/BTER:102:1-3:245.

Gulder TAM., Moore BS. 2010. Chasing the treasures of the sea - bacterial marine natural products. Current opinion in microbiology 12:252-260. DOI: 10.1016/j.mib.2009.05.002.Chasing.

Guo J., Rao Z., Yang T., Man Z., Xu M., Zhang X. 2014. High-level production of melanin by a novel isolate of Streptomyces kathirae. FEMS Microbiology Letters 357:85-91. DOI: 10.1111/1574-6968.12497.

Haber M.,and Ilan M.(2014).Diversity and antibacterial activity of bacteria cultured from Mediterranean Axinella spp. sponges. J.Appl.Microbiol. 116, 519-532.doi:10.1111/jam.12401

Haefner B. 2003. Drugs from the deep : marine natural products as drug candidates. Research Focus 8:536-544.

Haferburg G., Kloess G., Schmitz W., Kothe E. 2008. "Ni-struvite” - A new biomineral formed by a nickel resistant Streptomyces acidiscabies. Chemosphere 72:517-523. DOI: 10.1016/j.chemosphere.2008.02.050.

den Hengst CD., Buttner MJ. 2008. Redox control in actinobacteria. Biochimica et Biophysica Acta - General Subjects 1780:1201-1216. DOI: 10.1016/j.bbagen.2008.01.008. 
697 Henriques I., Tacão M., Leite L., Fidalgo C., Araújo S., Oliveira C., Alves A. 2016. Co-selection of antibiotic and metal ( loid )

698

699

700

701

702

703

704

705

706

707

708

709

710

711

712

713

714

715

716

717

718

719

720

721

722

723

724

725

726

727

728

729

730

731

732

733

734

735

736

737

738

739

resistance in gram-negative epiphytic bacteria from contaminated salt marshes. $\mathrm{Mpb}$. DOI:

10.1016/j.marpolbul.2016.05.031.

Hermanns YM., Biester H. 2013. Anthropogenic mercury signals in lake sediments from southernmost Patagonia, Chile. Science of the Total Environment 445-446:126-135. DOI: 10.1016/j.scitotenv.2012.12.034.

Hobman JL., Crossman LC. 2014. Bacterial antimicrobial metal ion resistance. Journal of Medical Microbiology 64:471-497. DOI: 10.1099/jmm.0.023036-0.

Hodges TW., Slattery M., Olson JB. 2012. Unique actinomycetes from marine caves and coral reef sediments provide novel PKS and NRPS biosynthetic gene clusters. Marine biotechnology 14:270-80. DOI: 10.1007/s10126-011-9410-7.

Huerta-Cepas J., Szklarczyk D., Forslund K., Cook H., Heller D., Walter MC., Rattei T., Mende DR., Sunagawa S., Kuhn M., Jensen L., von Mering C., Bork P. 2016. eggNOG 4.5: a hierarchical orthology framework with improved functional annotations for eukaryotic, prokaryotic and viral sequences. Nucleic Acids Res 44:D286-93. DOI: 10.1093/nar/gkv1248.

Iftime D., Kulik A., Härtner T., Rohrer S., Niedermeyer THJ., Stegmann E., Weber T., Wohlleben W. 2016. Identification and activation of novel biosynthetic gene clusters by genome mining in the kirromycin producer Streptomyces collinus Tü 365. Journal of Industrial Microbiology and Biotechnology 43:277-291. DOI: 10.1007/s10295-015-1685-7.

Ikeda H., Ishikawa J., Hanamoto A., Shinose M., Kikuchi H., Shiba T., Sakaki Y., Hattori M., Omura S. 2003. Complete genome sequence and comparative analysis of the industrial microorganism Streptomyces avermitilis. Nature biotechnology 21:526-531. DOI: 10.1038/nbt820.

Jensen PR., Gontang E., Mafnas C., Mincer TJ., Fenical W. 2005. Culturable marine actinomycete diversity from tropical Pacific Ocean sediments. Environmental microbiology 7:1039-48. DOI: 10.1111/j.1462-2920.2005.00785.x.

Jensen PR., Chavarria KL., Fenical W., Moore BS., Ziemert N. 2014. Challenges and triumphs to genomics-based natural product discovery. Journal of Industrial Microbiology and Biotechnology 41:203-209. DOI: 10.1007/s10295-013-1353-8.

Jiang S., Sun W., Chen M., Dai S., Zhang L., Liu Y., Lee KJ., Li X. 2007. Diversity of culturable actinobacteria isolated from marine sponge Haliclona sp. Antonie van Leeuwenhoek 92:405-16. DOI: 10.1007/s10482-007-9169-z.

Kalan L., Gessner A., Thaker MN., Waglechner N., Zhu X., Szawiola A., Bechthold A., Wright GD., Zechel DL. 2013. A cryptic polyene biosynthetic gene cluster in streptomyces calvus is expressed upon complementation with a functional bldA gene. Chemistry and Biology 20:1214-1224. DOI: 10.1016/j.chembiol.2013.09.006.

Katz L., Baltz RH. 2016. Natural product discovery: past, present, and future. Journal of Industrial Microbiology and Biotechnology 43:155-176. DOI: 10.1007/s10295-015-1723-5.

Kester DR., Duedall IW., Connors DN., Pytkowicz RM. 1967. Preparation of Artificial Seawater. Limnology and Oceanography 12:176-179. DOI: 10.4319/lo.1967.12.1.0176.

Kim J-S., Lee H-N., Kim P., Lee H-S., Eung Soo K. 2012. Negative role of wbIA in response to oxidative stress in Streptomyces coelicolor. Journal of Microbiology and Biotechnology 22:736-741. DOI: 10.4014/jmb.1112.12032.

Kim JN., Kim Y., Jeong Y., Roe JH., Kim BG., Cho3 BK. 2015. Comparative genomics reveals the core and accessory genomes of streptomyces species. Journal of Microbiology and Biotechnology 25:1599-1605. DOI: 10.4014/jmb.1504.04008.

Kim TK., Garson MJ., Fuerst JA. 2005. Marine actinomycetes related to the "Salinospora" group from the Great Barrier Reef sponge Pseudoceratina clavata. Environmental microbiology 7:509-518. DOI: 10.1111/j.1462-2920.2004.00716.x.

Komaki H., Ichikawa N., Hosoyama A., Fujita N., Igarashi Y. 2015. Draft Genome Sequence of Streptomyces sp. TP-A0871, a Producer of Heronamide C. Genome Announcements 3:e01429-15. DOI: 10.1128/genomeA.01429-15.

Krügel H., Krubasik P., Weber K., Saluz HP., Sandmann G. 1999. Functional analysis of genes from Streptomyces griseus involved in the synthesis of isorenieratene, a carotenoid with aromatic end groups, revealed a novel type of carotenoid desaturase. Biochimica et Biophysica Acta - Molecular and Cell Biology of Lipids 1439:57-64. DOI: 10.1016/S13881981(99)00075-X. 
740

741

742

743

744

745

746

747

748

749

750

751

752

753

754

755

756

757

758

759

760

761

762

763

764

765

766

767

768

769

770

771

772

773

774

775

776

777

778

779

780

781

782

Kuang W., Li J., Zhang S., Long L. 2015. Diversity and distribution of Actinobacteria associated with reef coral Porites lutea. Frontiers in Microbiology 6:1-13. DOI: 10.3389/fmicb.2015.01094.

Lam KS. 2006. Discovery of novel metabolites from marine actinomycetes. Current opinion in microbiology 9:245-51. DOI: 10.1016/j.mib.2006.03.004.

Van Lanen SG., Shen B. 2006. Microbial genomics for the improvement of natural product discovery. Current Opinion in Microbiology 9:252-260. DOI: 10.1016/j.mib.2006.04.002.

Laskaris P., Tolba S., Calvo-Bado L., Wellington L. 2010. Coevolution of antibiotic production and counter-resistance in soil bacteria. Environmental Microbiology 12:783-796. DOI: 10.1111/j.1462-2920.2009.02125.x.

Lee EJ., Karoonuthaisiri N., Kim HS., Park JH., Cha CJ., Kao CM., Roe JH. 2005. A master regulator oB governs osmotic and oxidative response as well as differentiation via a network of sigma factors in Streptomyces coelicolor. Molecular Microbiology 57:1252-1264. DOI: 10.1111/j.1365-2958.2005.04761.x.

Lee SH., Moon K., Kim H., Shin J., Oh DC., Oh KB. 2014. Bahamaolide A from the marine-derived Streptomyces sp. CNQ343 inhibits isocitrate lyase in Candida albicans. Bioorganic and Medicinal Chemistry Letters 24:4291-4293. DOI: 10.1016/j.bmcl.2014.07.021.

León J., Liza L., Soto I., Cuadra DL., Patiño L. 2007. Actinomycetes bioactivos de sedimento marino de la costa central del Perú. Revista Peruana de Microbiologia 14:259-270.

Li F., Jiang P., Zheng H., Wang S., Zhao G., Qin S., Liu Z. 2011. Draft genome sequence of the marine bacterium Streptomyces griseoaurantiacus M045, which produces novel manumycin-type antibiotics with a pABA core component. Journal of Bacteriology 193:3417-3418. DOI: 10.1128/JB.05053-11.

Li A-D., Li L-G., Zhang T. 2015. Exploring antibiotic resistance genes and metal resistance genes in plasmid metagenomes from wastewater treatment plants. Frontiers in Microbiology 6:1025. DOI: 10.3389/fmicb.2015.01025.

Lin Y., Hao X., Johnstone L., Miller SJ., Baltrus DA., Rensing C., Wei G. 2011. Draft genome of Streptomyces zinciresistens K42, a novel metal-resistant species isolated from copper-zinc mine tailings. Journal of Bacteriology 193:6408-6409. DOI: 10.1128/JB.06165-11.

Locatelli FM., Goo K-S., Ulanova D. 2016. Effects of trace metal ions on secondary metabolism and the morphological development of streptomycetes. Metallomics. DOI: 10.1039/C5MT00324E.

Magarvey N., Keller J., Bernan V., Dworkin M., Sherman DH. 2004. Isolation and characterization of novel marine-derived actinomycete taxa rich in bioactive metabolites. Applied and environmental microbiology 70:7520-9. DOI: 10.1128/AEM.70.12.7520-7529.2004.

Magarvey NA., Haltli B., He M., Greenstein M., Hucul JA. 2006. Biosynthetic pathway for mannopeptimycins, lipoglycopeptide antibiotics active against drug-resistant gram-positive pathogens. Antimicrobial Agents and Chemotherapy 50:21672177. DOI: 10.1128/AAC.01545-05.

Mahmoud HM., Kalendar AA. 2016. Coral-associated Actinobacteria: Diversity, abundance, and biotechnological potentials. Frontiers in Microbiology 7:1-13. DOI: 10.3389/fmicb.2016.00204.

Marcone GL., Carrano L., Marinelli F., Beltrametti F. 2010. Protoplast preparation and reversion to the normal filamentous growth in antibiotic-producing uncommon actinomycetes. The Journal of Antibiotics 63:83-88.

Martin JF., Liras P. 2012. Cascades and networks of regulatory genes that control antibiotic biosynthesis. In: Reprogrammin Microbial Metabolic Pathways. 159-179. DOI: 10.1007/978-94-007-5055-5.

McAlpine JB., Bachmann BO., Piraee M., Tremblay S., Alarco AM., Zazopoulos E., Farnet CM. 2005. Microbial genomics as a guide to drug discovery and structural elucidation: ECO-02301, a novel antifungal agent, as an example. Journal of Natural Products 68:493-496. DOI: 10.1021/np0401664.

Medema MH., Blin K., Cimermancic P., De Jager V., Zakrzewski P., Fischbach MA., Weber T., Takano E., Breitling R. 2011. AntiSMASH: Rapid identification, annotation and analysis of secondary metabolite biosynthesis gene clusters in bacterial 
and fungal genome sequences. Nucleic Acids Research 39:339-346. DOI: 10.1093/nar/gkr466.

784

785

786

787

788

789

790

791

792

793

794

795

796

797

798

799

800

801

802

803

804

805

806

807

808

809

810

811

812

813

814

815

816

817

818

819

820

821

822

823

824

825

826

827

828

829

Medema MH., Kottmann R., Yilmaz P., Cummings M., Biggins JB., Blin K., de Bruijn I., Chooi YH., Claesen J., Coates RC., CruzMorales P., Duddela S., Düsterhus S., Edwards DJ., Fewer DP., Garg N., Geiger C., Gomez-Escribano JP., Greule A., Hadjithomas M., Haines AS., Helfrich EJN., Hillwig ML., Ishida K., Jones AC., Jones CS., Jungmann K., Kegler C., Kim HU., Kötter P., Krug D., Masschelein J., Melnik A V., Mantovani SM., Monroe EA., Moore M., Moss N., Nützmann H-W., Pan G., Pati A., Petras D., Reen FJ., Rosconi F., Rui Z., Tian Z., Tobias NJ., Tsunematsu Y., Wiemann P., Wyckoff E., Yan X., Yim G., Yu F., Xie Y., Aigle B., Apel AK., Balibar CJ., Balskus EP., Barona-Gómez F., Bechthold A., Bode HB., Borriss R., Brady SF., Brakhage AA., Caffrey P., Cheng Y-Q., Clardy J., Cox RJ., De Mot R., Donadio S., Donia MS., van der Donk WA., Dorrestein PC., Doyle S., Driessen AJM., Ehling-Schulz M., Entian K-D., Fischbach MA., Gerwick L., Gerwick WH., Gross H., Gust B., Hertweck C., Höfte M., Jensen SE., Ju J., Katz L., Kaysser L., Klassen JL., Keller NP., Kormanec J., Kuipers OP., Kuzuyama T., Kyrpides NC., Kwon H-J., Lautru S., Lavigne R., Lee CY., Linquan B., Liu X., Liu W., Luzhetskyy A., Mahmud T., Mast Y., Méndez C., Metsä-Ketelä M., Micklefield J., Mitchell DA., Moore BS., Moreira LM., Müller R., Neilan BA., Nett M., Nielsen J., O'Gara F., Oikawa H., Osbourn A., Osburne MS., Ostash B., Payne SM., Pernodet J-L., Petricek M., Piel J., Ploux O., Raaijmakers JM., Salas JA., Schmitt EK., Scott B., Seipke RF., Shen B., Sherman DH., Sivonen K., Smanski MJ., Sosio M., Stegmann E., Süssmuth RD., Tahlan K., Thomas CM., Tang Y., Truman AW., Viaud M., Walton JD., Walsh CT., Weber T., van Wezel GP., Wilkinson B., Willey JM., Wohlleben W., Wright GD., Ziemert N., Zhang C., Zotchev SB., Breitling R., Takano E., Glöckner FO. 2015. The Minimum Information about a Biosynthetic Gene cluster (MIBiG) specification. Nature chemical biology 11:625-631. DOI: 10.1038/nchembio.1890.

Mincer TJ., Jensen PR., Kauffman C a., Fenical W. 2002. Widespread and persistent populations of a major new marine actinomycete taxon in ocean sediments. Applied and Environmental Microbiology 68:5005-5011. DOI: 10.1128/AEM.68.10.5005-5011.2002.

Montalvo NF., Mohamed NM., Enticknap JJ., Hill RT. 2005. Novel actinobacteria from marine sponges. Antonie van Leeuwenhoek 87:29-36. DOI: 10.1007/s10482-004-6536-x.

Newman DJ., Cragg GM. 2016. Natural products as sources of new drugs over the 30 years from 1981 to 2010. Journal of Natural Products 75:311-335. DOI: 10.1021/np200906s.

Van Nostrand JD., Khijniak T V., Gentry TJ., Novak MT., Sowder AG., Zhou JZ., Bertsch PM., Morris PJ. 2007. Isolation and characterization of four Gram-positive nickel-tolerant microorganisms from contaminated sediments. Microbial Ecology 53:670-682. DOI: 10.1007/s00248-006-9160-7.

Olano C., Gómez C., Pérez M., Palomino M., Pineda-Lucena A., Carbajo RJ., Braña AF., Méndez C., Salas JA. 2009. Deciphering Biosynthesis of the RNA Polymerase Inhibitor Streptolydigin and Generation of Glycosylated Derivatives. Chemistry and Biology 16:1031-1044. DOI: 10.1016/j.chembiol.2009.09.015.

Ostash B., Saghatelian A., Walker S. 2007. A Streamlined Metabolic Pathway for the Biosynthesis of Moenomycin A. Chemistry and Biology 14:257-267. DOI: 10.1016/j.chembiol.2007.01.008.

Pantoja S., Luis Iriarte J., Daneri G. 2011. Oceanography of the Chilean Patagonia. Continental Shelf Research 31:149-153. DOI: 10.1016/j.csr.2010.10.013.

Peláez F. 2006. The historical delivery of antibiotics from microbial natural products - Can history repeat? Biochemical Pharmacology 71:981-990. DOI: 10.1016/j.bcp.2005.10.010.

Pérez JM., Calderón IL., Arenas FA., Fuentes DE., Pradenas GA., Fuentes EL., Sandoval JM., Castro ME., Elías AO., Vásquez CC. 2007. Bacterial toxicity of potassium tellurite: Unveiling an ancient enigma. PLOS ONE 2. DOI: 10.1371/journal.pone.0000211.

Pham TM., Wiese J., Wenzel-Storjohann A., Imhoff JF. 2016. Diversity and antimicrobial potential of bacterial isolates associated with the soft coral Alcyonium digitatum from the Baltic Sea. Antonie van Leeuwenhoek, International Journal of General and Molecular Microbiology 109:105-119. DOI: 10.1007/s10482-015-0613-1.

Polti MA., Amoroso MJ., Abate CM. 2007. Chromium(VI) resistance and removal by actinomycete strains isolated from sediments. Chemosphere 67:660-667. DOI: 10.1016/j.chemosphere.2006.11.008.

Prabhu J., Schauwecker F., Grammel N., Keller U., Bernhard M. 2004. Functional expression of the ectoine hydroxylase gene (thpD) from Streptomyces chrysomallus in Halomonas elongata. Applied and environmental microbiology 70:3130-2. 
DOI: 10.1128/AEM.70.5.3130.

831

832

833

834

835

836

837

838

839

840

841

842

843

844

845

846

847

848

849

850

851

852

853

854

855

856

857

858

859

860

861

862

863

864

865

866

867

868

869

870

871

872

873

Qin Q-L., Li Y., Zhang Y-J., Zhou Z-M., Zhang W-X., Chen X-L., Zhang X-Y., Zhou B-C., Wang L., Zhang Y-Z. 2011. Comparative genomics reveals a deep-sea sediment-adapted life style of Pseudoalteromonas sp. SM9913. The ISME journal 5:274284. DOI: 10.1038/ismej.2010.103.

Ravel J., Diruggiero J., Robb FT., Hill RT., Ruggiero JDI. 2000. Cloning and Sequence Analysis of the Mercury Resistance Operon of Streptomyces sp. Strain CHR28 Reveals a Novel Putative Second Regulatory Gene Cloning and Sequence Analysis of the Mercury Resistance Operon of Streptomyces sp. Strain CHR28 Reveals a Nov. 182:1-6. DOI: 10.1128/JB.182.8.23452349.2000.Updated.

Ravel J., Schrempf H., Hill RT. 1998. Mercury resistance is encoded by transferable giant linear plasmids in two Chesapeake Bay Streptomyces strains. Applied and Environmental Microbiology 64:3383-3388.

Rensing C., Pribyl T., Nies DH. 1997. New functions for the three subunits of the CzcCBA cation-proton antiporter. Journal of Bacteriology 179:6871-6879.

Revenga JE., Campbell LM., Arribére MA., Ribeiro Guevara S. 2012. Arsenic, cobalt and chromium food web biodilution in a Patagonia mountain lake. Ecotoxicology and Environmental Safety 81:1-10. DOI: 10.1016/j.ecoenv.2012.03.014.

Ricci S., Janulczyk R., Björck L., Bjo L. 2002. The Regulator PerR Is Involved in Oxidative Stress Response and Iron Homeostasis and Is Necessary for Full Virulence of Streptococcus pyogenes The Regulator PerR Is Involved in Oxidative Stress Response and Iron Homeostasis and Is Necessary for Full Virul. Infection and Immunity 70:4968-4976. DOI: 10.1128/IAI.70.9.4968.

Rodriguez-Rojas F., Diaz-Vasquez W., Undabarrena A., Munoz-Diaz P., Arenas F., Vasquez C. 2015. Mercury-mediated crossresistance to tellurite in Pseudomonas spp. isolated from the Chilean Antarctic territory. Metallomics. DOI: 10.1039/C5MT00256G.

Romero D., Traxler MF., López D., Kolter R. 2012. Antibiotics as Signal Molecules. Chemical Reviews 111:5492-5505. DOI: 10.1021/cr2000509.Antibiotics.

Rother D., Mattes R., Altenbuchner J. 1999. Purification and characterization of MerR, the regulator of the broad-spectrum mercury resistance genes in Streptomyces lividans 1326. Molecular and General Genetics 262:154-162. DOI: $10.1007 / \mathrm{s} 004380051070$.

Ruiz B., Chávez A., Forero A., García-Huante Y., Romero A., Sánchez M., Rocha D., Sánchez B., Rodríguez-Sanoja R., Sánchez S., Langley E. 2010. Production of microbial secondary metabolites: regulation by the carbon source. Critical reviews in microbiology 36:146-67. DOI: 10.3109/10408410903489576.

Sadler R., Connell D. 2012. Global Distillation in an Era of Climate Change. In: Puzyn T ed. Organic Pollutants Ten Years After the Stockholm Convention - Environmental and Analytical Update. InTech, 191-216.

Sánchez S., Chávez A., Forero A., García-Huante Y., Romero A., Sánchez M., Rocha D., Sánchez B., Avalos M., Guzmán-Trampe S., Rodríguez-Sanoja R., Langley E., Ruiz B. 2010. Carbon source regulation of antibiotic production. Journal of Antibiotics 63:442-59. DOI: 10.1038/ja.2010.78.

Sander R., Keene WC., Pszenny AAP., Arimoto R., Ayers GP., Baboukas E., Cainey JM., Crutzen PJ., Duce RA., Hönninger G., Huebert BJ., Maenhaut W., Mihalopoulos N., Turekian VC., Van Dingenen R. 2003. Inorganic bromine in the marine boundary layer: a critical review. Atmospheric Chemistry and Physics Discussions 3:1301-1336. DOI: 10.5194/acpd-32963-2003.

Schmidt A., Haferburg G., Sineriz M., Merten D., Büchel G., Kothe E. 2005. Heavy metal resistance mechanisms in actinobacteria for survival in AMD contaminated soils. Chemie der Erde - Geochemistry 65:131-144. DOI: 10.1016/j.chemer.2005.06.006.

Schmidt A., Haferburg G., Schmidt A., Lischke U., Merten D., Ghergel F., Büchel G., Kothe E. 2009. Heavy metal resistance to the extreme: Streptomyces strains from a former uranium mining area. Chemie der Erde - Geochemistry 69:35-44. DOI: 10.1016/j.chemer.2007.11.002. 
874 Seaver LC., Imlay JA. 2001. Alkyl Hydroperoxide Reductase Is the Primary Scavenger of Endogenous Hydrogen Peroxide in

875 Escherichia coli. Journal of Bacteriology 183:7173-7181. DOI: 10.1128/JB.183.24.7173.

876

900

901

902

903

904

905

906

907

908

909

910

911

912

913

Sedlmeier R., Altenbuchner J. 1992. Cloning and Dna-Sequence Analysis of the Mercury Resistance Genes of StreptomycesLividans. Molecular \& General Genetics 236:76-85.

Seiler C., Berendonk TU. 2012. Heavy metal driven co-selection of antibiotic resistance in soil and water bodies impacted by agriculture and aquaculture. Frontiers in Microbiology 3:1-10. DOI: 10.3389/fmicb.2012.00399.

Silver S., Phung LT. 2005. A bacterial view of the periodic table: Genes and proteins for toxic inorganic ions. Journal of Industrial Microbiology and Biotechnology 32:587-605. DOI: 10.1007/s10295-005-0019-6.

Siñeriz ML., Kothe E., Abate CM. 2009. Cadmium biosorption by Streptomyces sp. F4 isolated from former uranium mine. Journal of Basic Microbiology 49:55-62. DOI: 10.1002/jobm.200700376.

Sivaperumal P., Kamala K., Rajaram R. 2015. Bioactive DOPA melanin isolated and characterised from a marine actinobacterium Streptomyces sp. MVCS6 from Versova coast. Natural product research 29:2117-2121. DOI: 10.1080/14786419.2014.988712.

Sobarzo, M., 2009. La Región de los fiordos de la zona sur de Chile, in: Aspectos Oceanográficos. p. 6.

Storz G., Imlay JA. 1999. Oxidative stress. Current Opinion in Microbiology 2:188-194. DOI: 10.1016/S1369-5274(99)80033-2.

Studholme DJ. 2016. Genome Update. Let the consumer beware: Streptomyces genome sequence quality. Microbial Biotechnology 9:3-7. DOI: 10.1111/1751-7915.12344.

Subramani R., Aalbersberg W. 2012. Marine actinomycetes: an ongoing source of novel bioactive metabolites. Microbiological research 167:571-80. DOI: 10.1016/j.micres.2012.06.005.

Sun W., Zhang F., He L., Karthik L., Li Z. 2015. Actinomycetes from the South China Sea sponges: Isolation, diversity, and potential for aromatic polyketides discovery. Frontiers in Microbiology 6:1-15. DOI: 10.3389/fmicb.2015.01048.

Tamura K., Stecher G., Peterson D., Filipski A., Kumar S. 2013. MEGA6: Molecular Evolutionary Genetics Analysis version 6.0. Molecular biology and evolution 30:2725-9. DOI: 10.1093/molbev/mst197.

Tang J., Liu X., Peng J., Tang Y., Zhang Y. 2015a. Genome sequence and genome mining of a marine-derived antifungal bacterium Streptomyces sp. M10. Applied Microbiology and Biotechnology 99:2763-2772. DOI: 10.1007/s00253-0156453-0.

Tang X., Li J., Millán-Aguiñaga N., Zhang JJ., O’Neill EC., Ugalde JA., Jensen PR., Mantovani SM., Moore BS. 2015b. Identification of Thiotetronic Acid Antibiotic Biosynthetic Pathways by Target-directed Genome Mining. ACS Chemical Biology 10:28412849. DOI: 10.1021/acschembio.5b00658.

Tatusova T., DiCuccio M., Badretdin A., Chetvernin V., Nawrocki EP., Zaslavsky L., Lomsadze A., Pruitt KD., Borodovsky M., Ostell J. 2016. NCBI prokaryotic genome annotation pipeline. Nucleic Acids Research:gkw569. DOI: 10.1093/nar/gkw569.

Taylor DE. 1999. Bacterial tellurite resistance. Trends in Microbiology 7:111-115. DOI: 10.1016/S0966-842X(99)01454-7.

Tian X., Zhang Z., Yang T., Chen M., Li J., Chen F., Yang J., Li W., Zhang B., Zhang Z., Wu J., Changsheng Z., Long L., Jingfa X. 2016. Comparative Genomics Analysis of Streptomyces Species Reveals Their Adaptation to the Marine Environment and Their Diversity at the Genomic Level. Frontiers in Microbiology 7:1-16. DOI: 10.3389/fmicb.2016.00998.

Tremaroli V., Fedi S., Zannoni D. 2007. Evidence for a tellurite-dependent generation of reactive oxygen species and absence of a tellurite-mediated adaptive response to oxidative stress in cells of Pseudomonas pseudoalcaligenes KF707. Archives of Microbiology 187:127-135. DOI: 10.1007/s00203-006-0179-4.

Turner RJ., Aharonowitz Y., Weiner JH., Taylor DE. 2001. Glutathione is a target in tellurite toxicity and is protected by tellurite resistance determinants in Escherichia coli. Canadian journal of microbiology 47:33-40. DOI: 10.1139/cjm-47-1-33.

Undabarrena A., Beltrametti F., Claverías FP., González M. 2016a. Exploring the Diversity and Antimicrobial Potential of Marine 
915

916

917

918

919

920

921

922

923

924

925

926

927

928

929

930

931

932

933

934

935

936

937

938

939

940

941

942

943

944

945

946

947

948

949

950

951

952

953

954

955

956

957

Actinobacteria from the Comau Fjord in Northern Patagonia , Chile. Frontiers in Microbiology 7:1-16. DOI: 10.3389/fmicb.2016.01135.

Undabarrena A., Ugalde JA, Castro-Nallar E., Seeger M., Cámara BP. 2016b. Genome sequence of Streptomyces sp. strain H-KF8, a marine actinomycete isolated from a northern Chilean Patagonian fjord. Genome Announcements. Accepted.

Valliappan K., Sun W., Li Z. 2014. Marine actinobacteria associated with marine organisms and their potentials in producing pharmaceutical natural products. Applied Microbiology and Biotechnology 98:7365-7377. DOI: 10.1007/s00253-0145954-6.

Vicente J., Stewart A., Song B., Hill RT., Wright JL. 2013. Biodiversity of Actinomycetes associated with Caribbean sponges and their potential for natural product discovery. Marine biotechnology (New York, N.Y.) 15:413-24. DOI: 10.1007/s10126013-9493-4.

Vilos C., Morales FA., Solar PA., Herrera NS., Gonzalez-Nilo FD., Aguayo DA., Mendoza H., Comer J., Bravo ML., González PA., Kato S., Cuello MA., Alonso C., Bravo EJ., Bustamante El., Owen GI., Velasquez LA. 2013. Paclitaxel-PHBV Nanoparticles and Their Toxicity to Endometrial and Primary Ovarian Cancer Cells. Biomaterials 34:4098-4108.

Wacaster S. 2015. The mineral industry of Chile. U.S. Geological Survey.

Wallhausser KH., Nesemann G., Prave P., Steigler A. 1965. Moenomycin, a new antibiotic. I. Fermentation and isolation. Antimicrobial Agents Chemotherapy:734-736.

Wang L., Chen S., Xiao X., Huang X., You D., Zhou X., Deng Z. 2006. arsRBOCT arsenic resistance system encoded by linear plasmid pHZ227 in Streptomyces sp. strain FR-008. Applied and Environmental Microbiology 72:3738-3742. DOI: 10.1128/AEM.72.5.3738-3742.2006.

Weber T., Welzel K., Pelzer S., Vente A., Wohlleben W. 2003. Exploiting the genetic potential of polyketide producing streptomycetes. Journal of Biotechnology 106:221-232. DOI: 10.1016/j.jbiotec.2003.08.004.

Weber T., Laiple KJ., Pross EK., Textor A., Grond S., Welzel K., Pelzer S., Vente A., Wohlleben W. 2008. Molecular Analysis of the Kirromycin Biosynthetic Gene Cluster Revealed $\beta$-Alanine as Precursor of the Pyridone Moiety. Chemistry and Biology 15:175-188. DOI: 10.1016/j.chembiol.2007.12.009.

Weber T., Blin K., Duddela S., Krug D., Kim HU., Bruccoleri R., Lee SY., Fischbach MA., Müller R., Wohlleben W., Breitling R., Takano E., Medema MH. 2015. antiSMASH 3.0-a comprehensive resource for the genome mining of biosynthetic gene clusters. Nucleic acids research 43:W237-43. DOI: 10.1093/nar/gkv437.

Westerdahl A., Olsson CJ., Kjelleberg S., Conway PL. 1991. Isolation and Characterization of Turbot (Scophtalmus maximus)Associated Bacteria with Inhibitory Effects against Vibrio anguillarum. Applied and environmental microbiology 57:22232228.

Yagüe P., López-García MT., Rioseras B., Sánchez J., Manteca Á. 2013. Pre-sporulation stages of Streptomyces differentiation: State-of-the-art and future perspectives. FEMS Microbiology Letters 342:79-88. DOI: 10.1111/1574-6968.12128.

Yuan M., Yu Y., Li H-R., Dong N., Zhang X-H. 2014. Phylogenetic diversity and biological activity of actinobacteria isolated from the Chukchi Shelf marine sediments in the Arctic Ocean. Marine drugs 12:1281-97. DOI: 10.3390/md12031281.

Zazopoulos E., Huang K., Staffa A., Liu W., Bachmann BO., Nonaka K., Ahlert J., Thorson JS., Shen B., Farnet CM. 2003. A genomics-guided approach for discovering and expressing cryptic metabolic pathways. Nature biotechnology 21:187190. DOI: $10.1038 / \mathrm{nbt} 784$.

Zotchev S.B (2014). Genomics-based insights into the evolution of secondary metabolite biosynthesis in actinomycete bacteria. In Evolutionary Biology: Genome Evolution, Speciation, Coevolution and Origin of Life, ed P. Pontarotti (Cham: Springer International Publishing), 35-46.

Zhang H., Lee YK., Zhang W., Lee HK. 2006. Culturable actinobacteria from the marine sponge Hymeniacidon perleve: isolation and phylogenetic diversity by $16 \mathrm{~S}$ rRNA gene-RFLP analysis. Antonie van Leeuwenhoek 90:159-69. DOI: 10.1007/s10482006-9070-1. 
958

959

960

961

962

963

964

965

966

967
Zhang H., Wang H., Wang Y., Cui H., Xie Z., Pu Y., Pei S., Li F., Qin S. 2012. Genomic sequence-based discovery of novel angucyclinone antibiotics from marine Streptomyces sp. W007. FEMS Microbiology Letters 332:105-112. DOI: 10.1111/j.1574-6968.2012.02582.x.

Zhao B., Lin X., Lei L., Lamb DC., Kelly SL., Waterman MR., Cane DE. 2008. Biosynthesis of the sesquiterpene antibiotic albaflavenone inStreptomyces coelicolor A3(2). The Journal of biological chemistry 283:8183-8189. DOI: 10.1074/jbc.M710421200.

Zhu XM., HackI S., Thaker MN., Kalan L., Weber C., Urgast DS., Krupp EM., Brewer A., Vanner S., Szawiola A., Yim G., Feldmann J., Bechthold A., Wright GD., Zechel DL. 2015. Biosynthesis of the Fluorinated Natural Product Nucleocidin in Streptomyces calvus Is Dependent on the bldA-Specified Leu-tRNAUUA Molecule. ChemBioChem 16:2498-2506. DOI: 10.1002/cbic.201500402. 
968 Tables

969 Table 1. Antibacterial activity of Streptomyces sp. H-KF8 in several culture media.

\begin{tabular}{lccccc}
\hline \multirow{2}{*}{ Medium } & \multicolumn{5}{c}{ Bacterial strains $^{\mathrm{a}}$} \\
\cline { 2 - 6 } & STAU & LIMO & PSAU & SAEN & ESCO \\
\hline \hline ISP1 & +++ & +++ & - & +++ & +++ \\
ISP2 & +++ & $+/-$ & $+/-$ & - & + \\
ISP3 & + & + & - & - & + \\
ISP4 & + & - & - & - & - \\
ISP5 & + & - & - & - & - \\
ISP6 & ++ & +++ & - & + & + \\
ISP7 & +++ & - & - & $+/-$ & ++ \\
ISP9 & +++ & +++ & - & - & - \\
TSA-ASW & +++ & $+/-$ & - & - & + \\
MA & +++ & +++ & - & - & ++ \\
King B & - & $+/-$ & - & - & - \\
Medium V & ++ & ++ & - & $+/-$ & +++ \\
LB-ASW & +++ & ++ & - & $+/-$ & - \\
Actino Agar & - & - & - & - & - \\
NaST21Cx & - & - & - & - & - \\
\hline
\end{tabular}

$970 *_{-}$, no inhibition; +/-, attenuated growth; +, <50\% growth inhibition ( $\left.1-5 \mathrm{~mm}\right) ;++, 50 \%$ growth inhibition 971 (6-10 mm); +++, >50\% growth inhibition ( $\geq 11 \mathrm{~mm})$

972 aSTAU, S. aureus; LIMO, L. monocytogenes; PSAU, P. aeruginosa; SAEN, S. enterica; ESCO, E. coli. 
973 Table 2. COGs distribution of genes with coding sequences in Streptomyces sp. H-KF8.

\begin{tabular}{lccc}
\hline \multicolumn{1}{c}{ COG functional categories } & Abbreviation & $\mathrm{N}^{\circ}$ of genes & Percentage (\%) \\
\hline \hline Energy production and conversion & $\mathrm{C}$ & 275 & 4.18 \\
Cell division and chromosome partitioning & $\mathrm{D}$ & 41 & 0.62 \\
Amino acid transport and metabolism & $\mathrm{E}$ & 322 & 4.90 \\
Nucleotide transport and metabolism & $\mathrm{F}$ & 89 & 1.35 \\
Carbohydrate transport and metabolism & $\mathrm{G}$ & 362 & 5.51 \\
Coenzyme transport and metabolism & $\mathrm{H}$ & 136 & 2.07 \\
Lipid metabolism & $\mathrm{I}$ & 142 & 2.16 \\
Translation & $\mathrm{J}$ & 168 & 2.56 \\
Transcription & $\mathrm{K}$ & 522 & 7.94 \\
DNA replication and repair & $\mathrm{L}$ & 217 & 3.30 \\
Cell envelope biogenesis, outer membrane & $\mathrm{M}$ & 169 & 2.57 \\
Cell motility & $\mathrm{N}$ & 0 & 0.00 \\
Post-translational modification, protein turnover, chaperones & $\mathrm{O}$ & 135 & 2.05 \\
Inorganic ion transport and metabolism & $\mathrm{P}$ & 223 & 3.39 \\
Secondary metabolism & $\mathrm{Q}$ & 148 & 2.25 \\
General function prediction only & $\mathrm{R}$ & 238 & 3.62 \\
Function unknown & $\mathrm{S}$ & 2111 & 32.11 \\
Signal transduction & $\mathrm{T}$ & 283 & 4.30 \\
Defense mechanisms & $\mathrm{V}$ & 185 & 2.81 \\
Not in COGs & - & 808 & 12.29 \\
\hline
\end{tabular}

974

975 
976 Table 3. Biosynthetic gene clusters (BGCs) for secondary metabolites in Streptomyces sp. H-KF8.

\begin{tabular}{|c|c|c|c|c|}
\hline antiSMASH type descriptor & Scaffold & Length (bp) & $\begin{array}{l}\text { Predicted product } \\
\qquad\left(\%^{\mathrm{a}}\right)\end{array}$ & MIBiG-ID \\
\hline NRPS & tig_02 & 81285 & Streptolydigin (13\%) & BGC0001046 \\
\hline NRPS & tig_02 & 79174 & Mannopeptimycin (7\%) & BGC0000388 \\
\hline PKS T1 & tig_138 & 33925 & Kirromycin (6\%) & BGC0001070 \\
\hline PKS T2 & tig_139 & 42512 & Spore Pigment (83\%) & BGC0000271 \\
\hline NRPS-PKS T1 & tig_138 & 50808 & SGR PTMS (100\%) & BGC0001043 \\
\hline NRPS-PKS T1 & tig_139 & 52764 & Neomycin (5\%) & BGC0000710 \\
\hline NRPS-PKS T1 & tig_02 & 56103 & Himastatin (12\%) & BGC0001117 \\
\hline NRPS-PKS T3 & tig_02 & 54318 & Furaquinocin A (21\%) & BGC0001078 \\
\hline Terpene-Siderophore & tig_02 & 50603 & Isorenieratene (100\%) & BGC0000664 \\
\hline Nucleoside-Phosphoglycolipid & tig_00 & 35469 & Moenomycin (100\%) & BGC0000805 \\
\hline Oligosaccharide-PKS T1 & tig_16 & 42574 & Stambomycin (52\%) & BGC0000151 \\
\hline Lantipeptide-PKS T1 & tig_138 & 61004 & unknown & - \\
\hline Terpene & tig_02 & 26858 & Hopene (76\%) & BGC0000663 \\
\hline Terpene & tig_00 & 20992 & unknown & - \\
\hline Terpene & tig_02 & 21253 & unknown & - \\
\hline Terpene & tig_02 & 22162 & unknown & - \\
\hline Terpene & tig_138 & 21220 & Albaflavenone (100\%) & BGC0000660 \\
\hline Lantipeptide & tig_02 & 21819 & unknown & - \\
\hline Lantipeptide & tig_139 & 24585 & unknown & - \\
\hline Bacteriocin & tig_02 & 11412 & unknown & - \\
\hline Lassopeptide & tig_10 & 22692 & unknown & - \\
\hline Siderophore & tig_139 & 11808 & Desferrioxiamine B (83\%) & BGC0000940 \\
\hline Butyrolactone & tig_14 & 11073 & Griseoviridin/Viridogrisein (11\%) & BGC0000459 \\
\hline Ectoine & tig_139 & 10398 & Ectoine (100\%) & BGC0000853 \\
\hline Melanin & tig_139 & 10509 & Melanin (100\%) & BGC0000910 \\
\hline Other & tig_00 & 43290 & Stenothricin (13\%) & BGC0000431 \\
\hline
\end{tabular}

977 Percentage of genes from known BGCs that show similarity to genes predicted for BGCs from Streptomyces sp. 978H-KF8. 


\section{Figures}
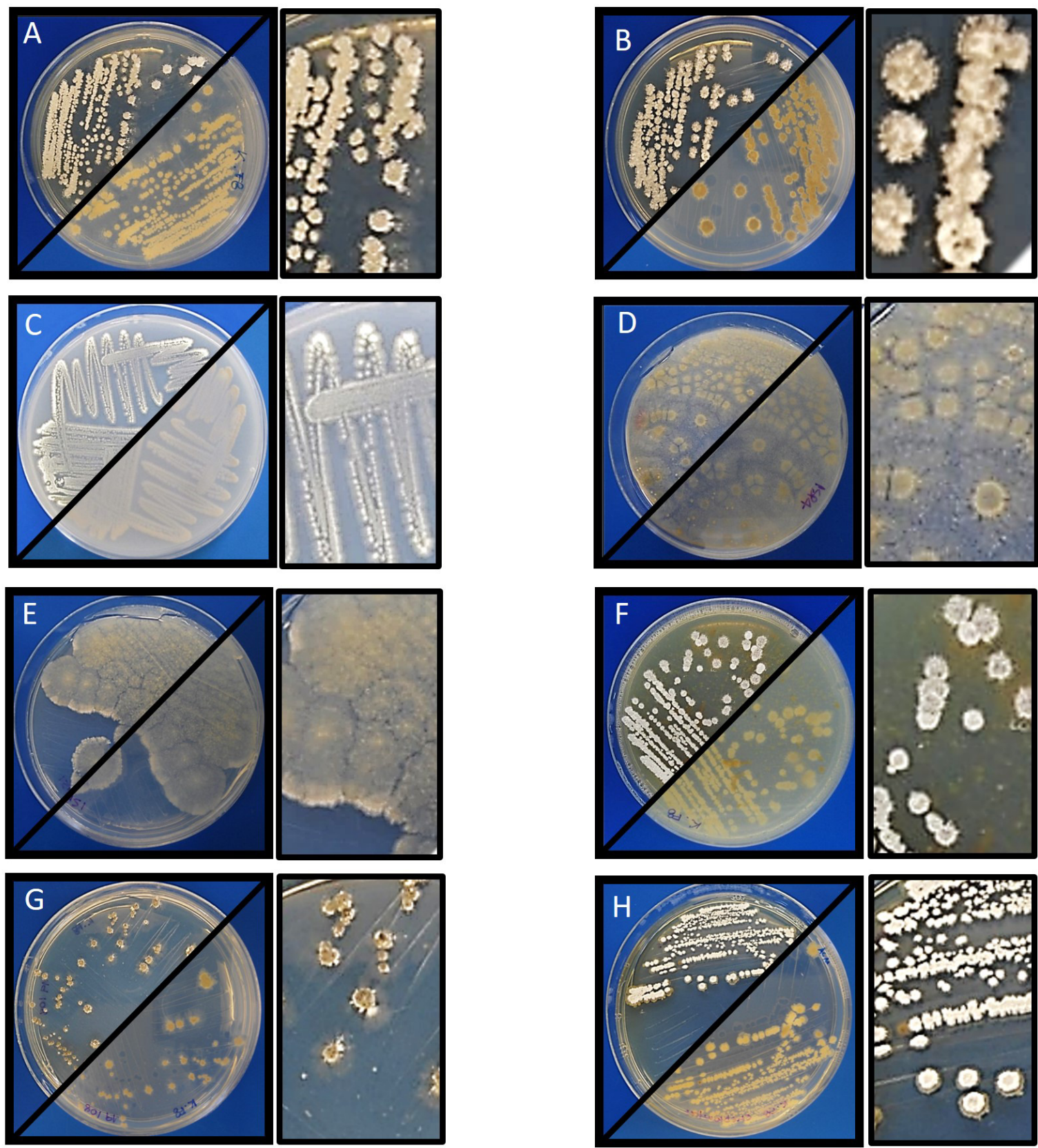

980

981 Figure 1. Morphology of Streptomyces sp. H-KF8. Macrocolony showing anverse and reverse growth in 982 several media. Inset shows a zoom of colony morphology. A) ISP1-ASW; B) ISP2-ASW); C) ISP3-ASW; D) 983 ISP4-ASW; E) ISP5-ASW; F) ISP6-ASW; G) Marine Agar (MA); H) TSA-ASW. 

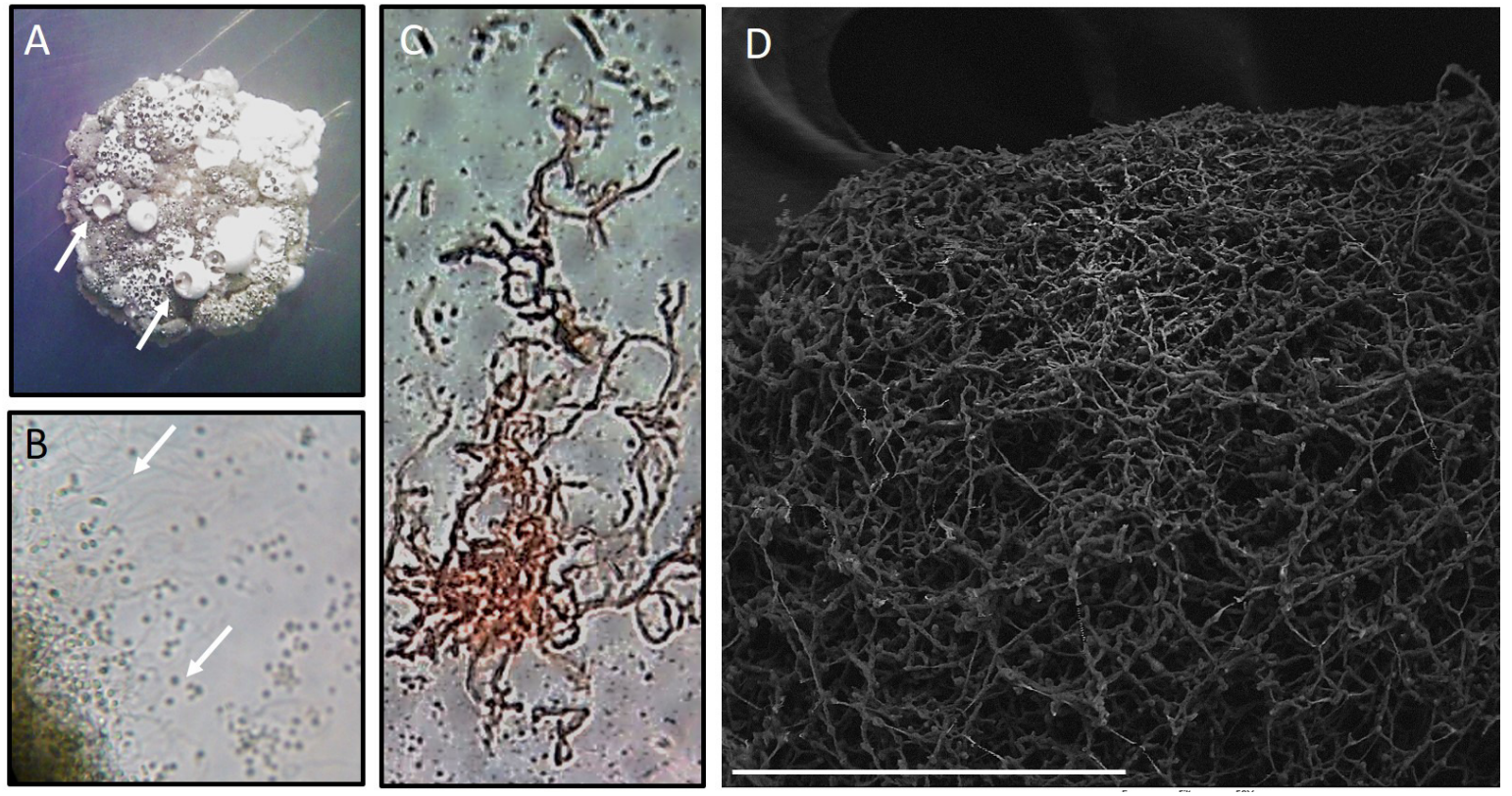

Figure 2. Microscopy of Streptomyces sp. H-KF8. A) Stereoscope zoom of a macrocolony grown in ISP2ASW agar plate. Arrows shows exudates. B) Optic Microscopy image at $1000 X$. Arrows indicate hyphae and spores, respectively.

C) Streptomyces sp. H-KF8 gram staining, showing hyphae. D) Scanning Electron Microscopy (LVEM) image of Streptomyces sp. H-KF8 grown on ISP3-ASW agar plates for 21 days. Bar represent $100 \mu \mathrm{m}$. 

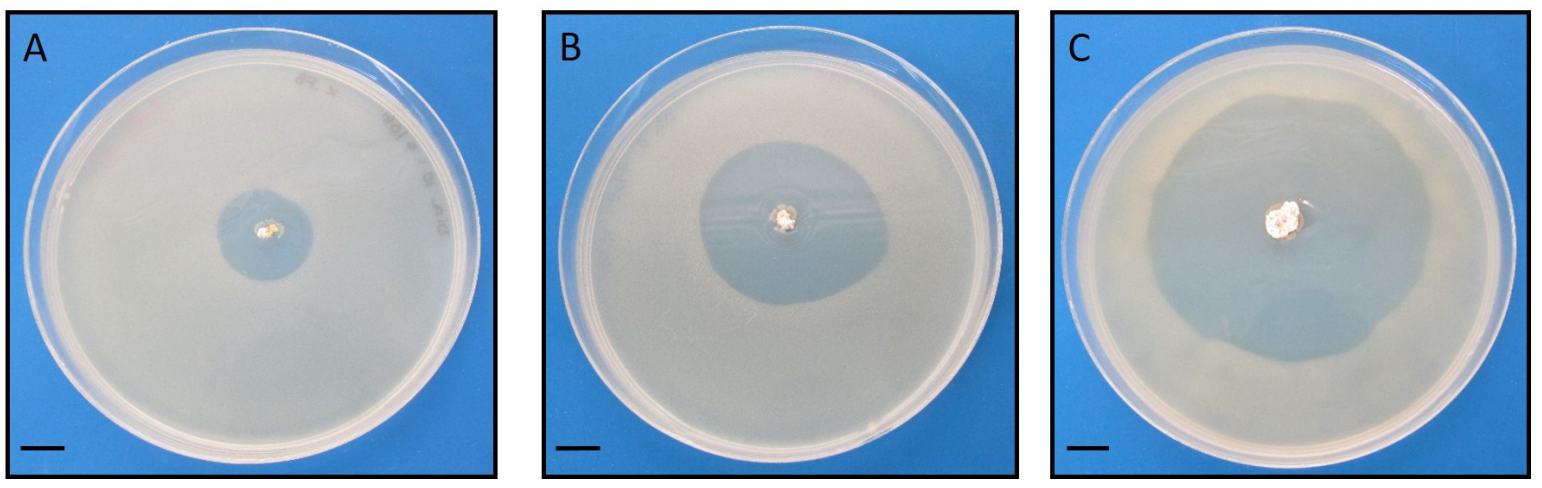

991 Figure 3. Antibacterial activity of Streptomyces sp. H-KF8. Photographs depict inhibition zone against 992 Staphylococcus aureus. Bar represents $1 \mathrm{~mm}$. Time course was performed using the double-layer 993 method, at various incubation days: A) 6 days; B) 9 days; C) 15 days. 


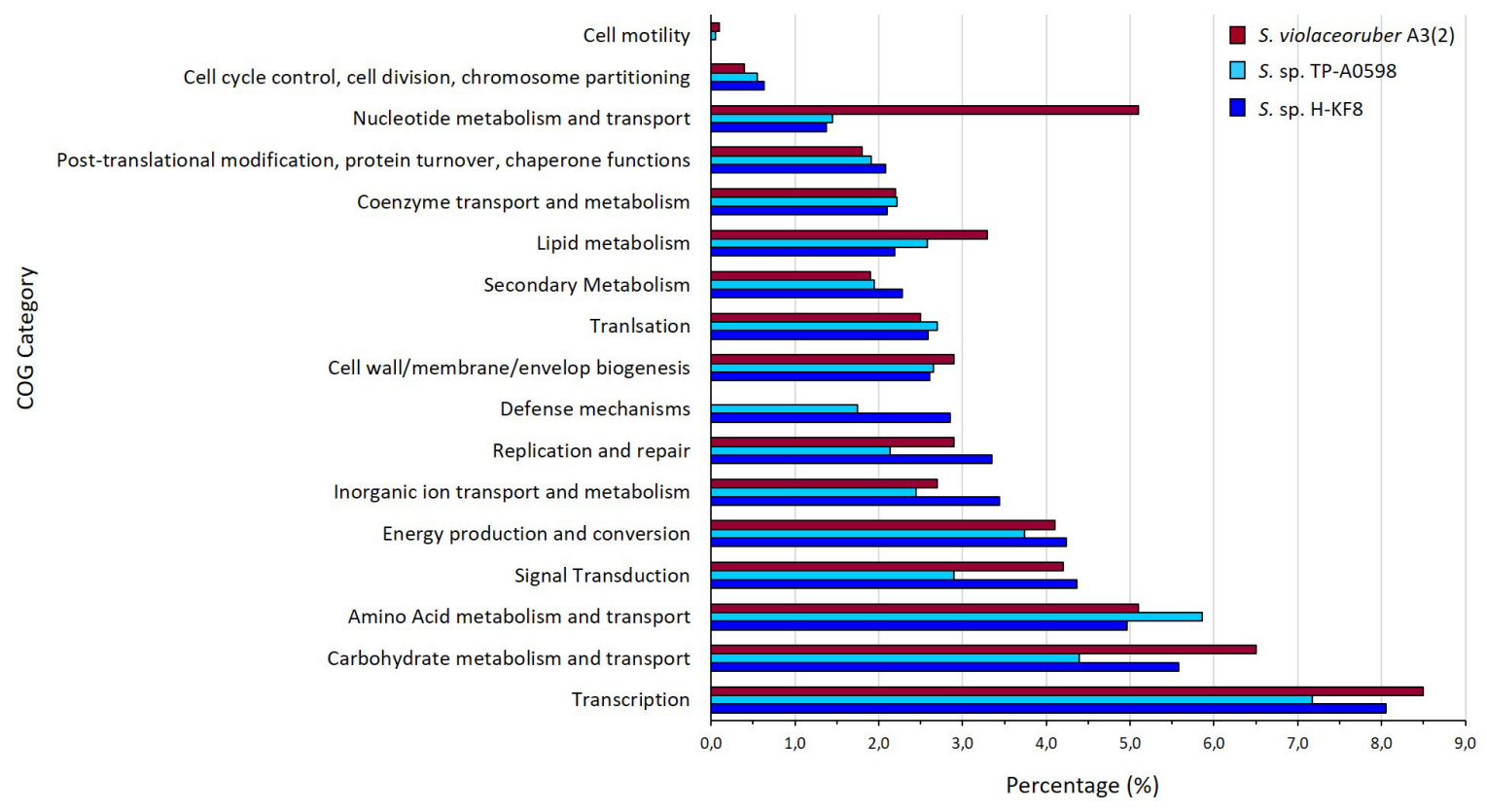

Figure 4. Comparative genomics of COGs categories. Percentage of each COG category is shown for the different Streptomyces species, where blue is Streptomyces sp. H-KF8; light blue is the marine-derived Streptomyces sp. TP-A0598; and red is the soil-derived Streptomyces violaceoruber A3(2). 


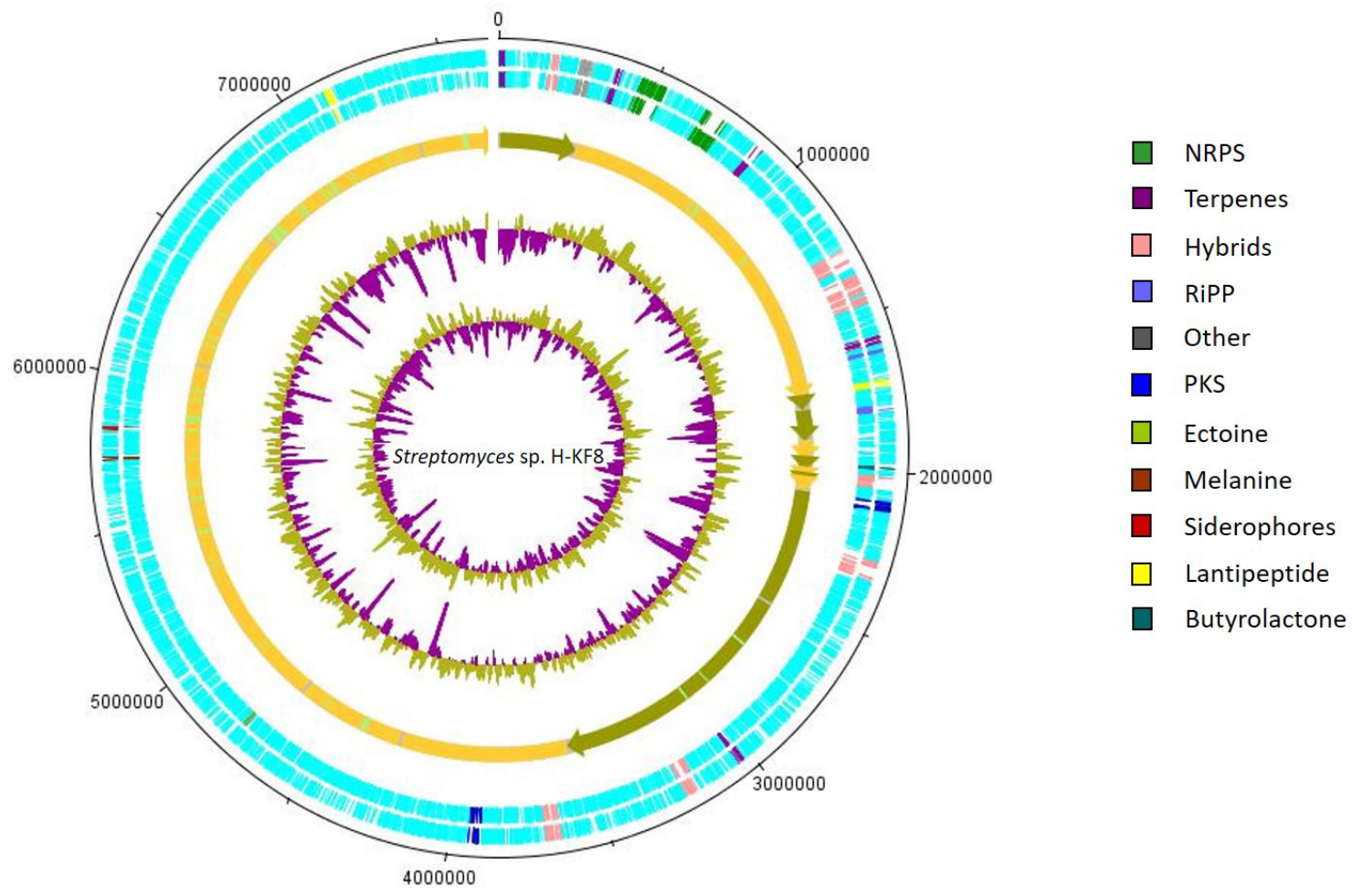

Figure 5. Representation of chromosome features and BGCs of Streptomyces sp. H-KF8. Colors depict the different classification types of secondary metabolism gene clusters along the sequenced genome. NRPS, Non-ribosomal peptide synthetase; PKS, polyketide synthase; RiPP, ribosomally synthesized and post-translationally modified peptides. From outside inward: DNA strands reverse and forward; contigs; GC content; GC skew. 
A

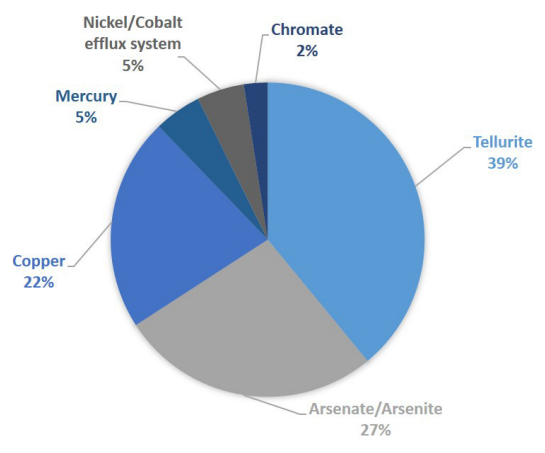

B

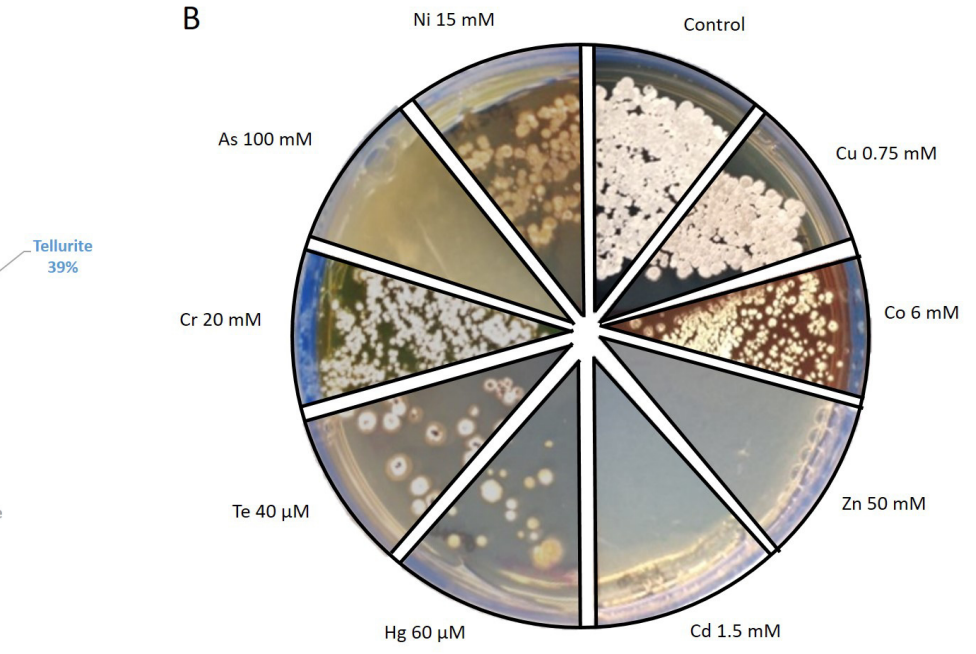

1006 Figure 6. Metal-tolerance response in Streptomyces sp. H-KF8. A) Genetic determinants involved in metal-resistance observed by genome mining. B) Functional response of metal-resistance in TSA-ASW 1008 agar plates. Images show maximum concentration of metal(loids) where growth of Streptomyces sp. $\mathrm{H}$ KF8 was observed. Concentrations below these values also presented growth. Control, agar plate 1010 without any metal. 

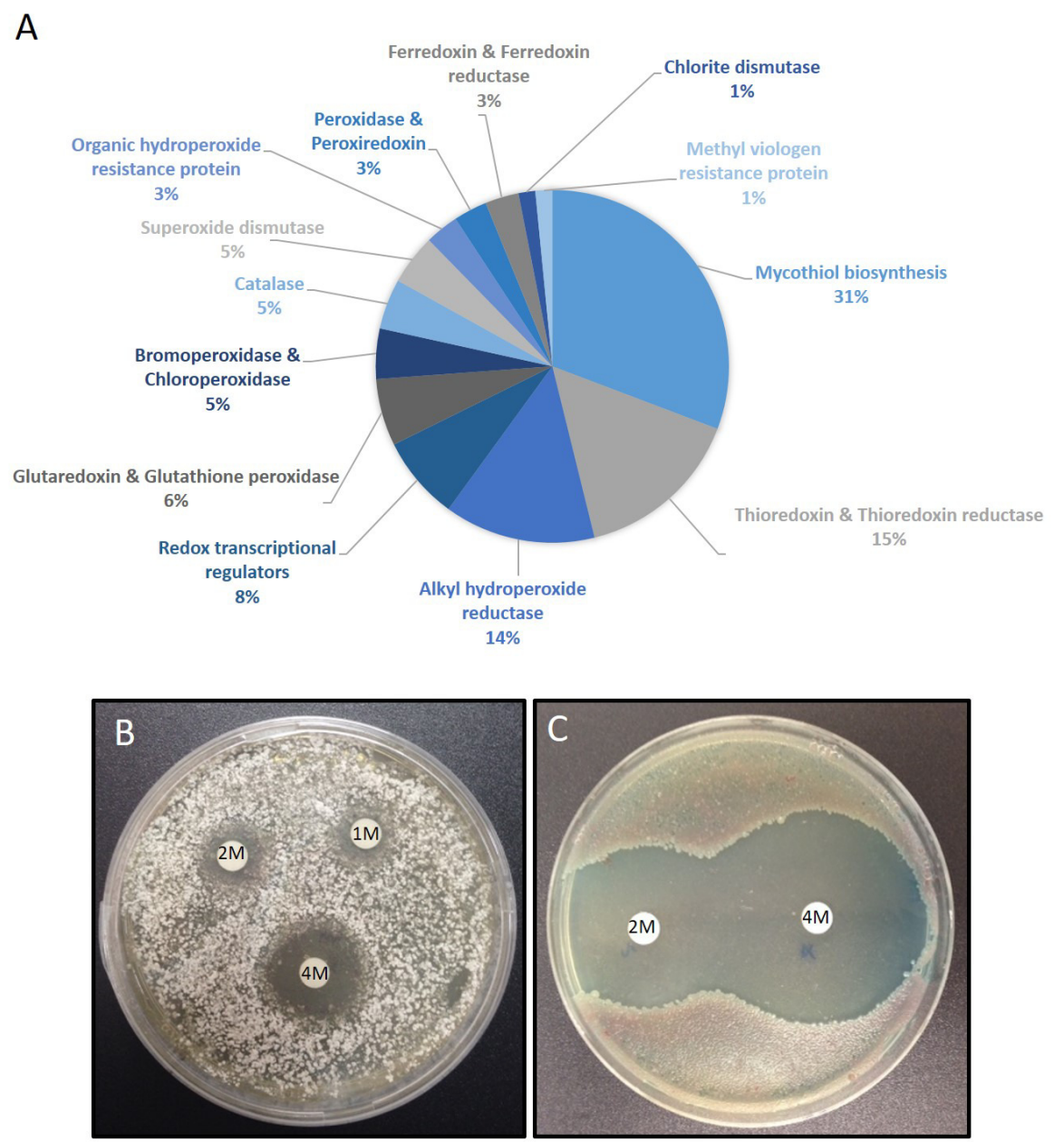

D

- S. violaceoruber $\mathrm{A} 3(2)$

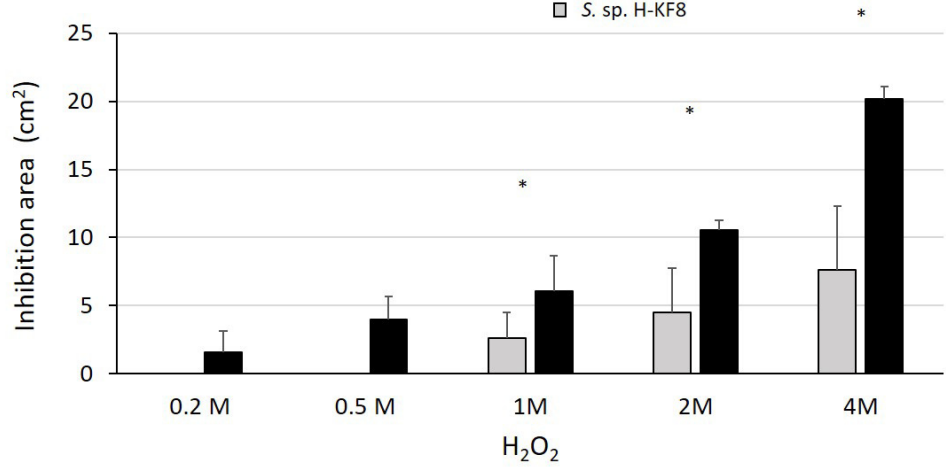

1011

1012 Figure 7. Oxidative stress response of Streptomyces sp. H-KF8. A) Genetic determinants involved in 1013 oxidative stress-resistance observed by genome mining. Functional response of B) Streptomyces sp. H1014 KF8 and C) Streptomyces violaceoruber A3(2) respectively, showing comparative inhibition zones with hydrogen peroxide where the concentration of hydrogen peroxide used in each disk is shown. D) Quantitative assay of inhibition area of both Streptomyces strains facing several concentrations of hydrogen peroxide. Asterisks indicate significant differences between strains ( $t$-Test considering a $p$ value $<0.01$ ). 
A

B
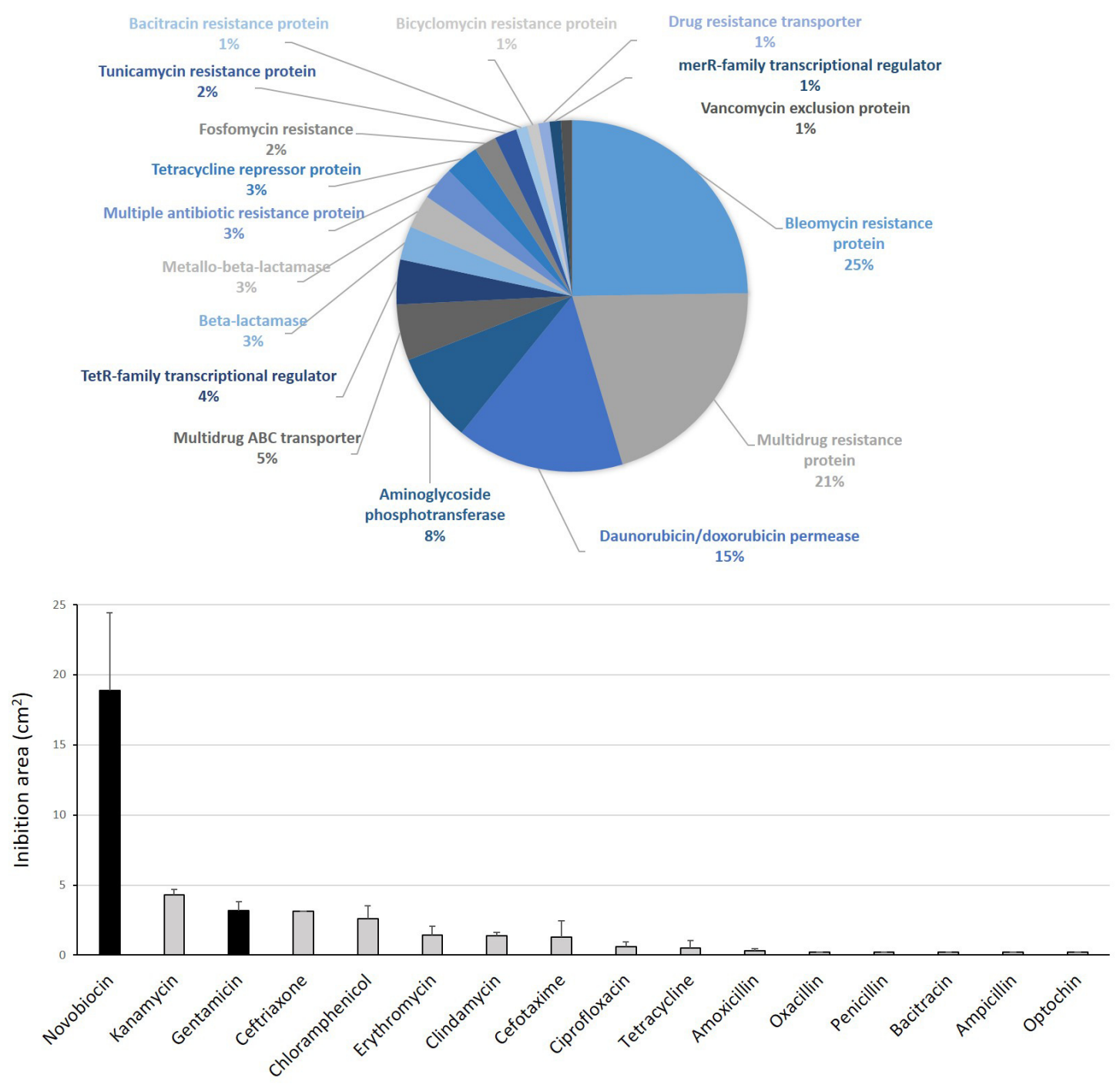

Antibiotics

Fig. 8. Antibiotic-resistance response in Streptomyces sp. H-KF8. A) Genetic determinants involved in antibiotic-resistance observed by genome mining. B) Functional response of antibiotic-resistance in $\mathrm{MH}-$ ASW agar plates. Black columns indicate susceptibility to the antibiotic tested and grey columns indicate resistance to the antibiotic tested. 